\title{
Use of the internal mammary artery as a coronary artery bypass graft
}

Citation for published version (APA):

Krijne, R. (1994). Use of the internal mammary artery as a coronary artery bypass graft. [Doctoral Thesis, Maastricht University]. Datawyse / Universitaire Pers Maastricht. https://doi.org/10.26481/dis.19940623rk

Document status and date:

Published: 01/01/1994

DOI:

10.26481/dis.19940623rk

Document Version:

Publisher's PDF, also known as Version of record

\section{Please check the document version of this publication:}

- A submitted manuscript is the version of the article upon submission and before peer-review. There can be important differences between the submitted version and the official published version of record.

People interested in the research are advised to contact the author for the final version of the publication, or visit the DOI to the publisher's website.

- The final author version and the galley proof are versions of the publication after peer review.

- The final published version features the final layout of the paper including the volume, issue and page numbers.

Link to publication

\footnotetext{
General rights rights.

- You may freely distribute the URL identifying the publication in the public portal. please follow below link for the End User Agreement:

www.umlib.nl/taverne-license

Take down policy

If you believe that this document breaches copyright please contact us at:

repository@maastrichtuniversity.nl

providing details and we will investigate your claim.
}

Copyright and moral rights for the publications made accessible in the public portal are retained by the authors and/or other copyright owners and it is a condition of accessing publications that users recognise and abide by the legal requirements associated with these

- Users may download and print one copy of any publication from the public portal for the purpose of private study or research.

- You may not further distribute the material or use it for any profit-making activity or commercial gain

If the publication is distributed under the terms of Article $25 \mathrm{fa}$ of the Dutch Copyright Act, indicated by the "Taverne" license above, 
USE OF THE INTERNAL MAMMARY ARTERY AS A CORONARY ARTERY BYPASS GRAFT 
Production: DATAWYSE | Universitaire Pers Maastricht

\section{CIP-DATA KONINKLIJKE BIBLIOTHEEK, DEN HAAG}

Krijne, Ruud

Use of the internal mammary artery as a coronary artery bypass graft / Ruud Krijne. - Maastricht : Universitaire Pers Maastricht. - Ill.

Thesis Maastricht. With ref. - With summary in Dutch and German.

ISBN 90-5278-147-8

Subject headings: mammary artery / cardiac surgery / Doppler 


\section{USE OF THE INTERNAL MAMMARY ARTERY AS A CORONARY ARTERY BYPASS GRAFT}

PROEFSCHRIFT

ter verkrijging van de graad van doctor aan de Rijksuniversiteit Limburg te Maastricht, op gezag van de Rector Magnificus, Prof. dr. H. Philipsen, volgens het besluit van het College van Dekanen, in het openbaar te verdedigen op donderdag 23 juni 1994 om 14.00 uur

door

Ruud Krijne

geboren te Beek en Donk

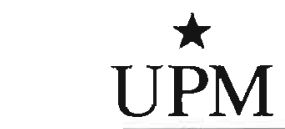




\section{Promotor:}

\section{Prof.dr. H.J.J. Wellens}

\section{Beoordelingscommissie:}

Prof.dr. O.C.K.M. Penn (voorzitter)

Dr. F.W.H.M. Bär

Prof.dr. J.J. Bredée (Universiteit Utrecht)

Prof.dr. K.I. Lie (Rijksuniversiteit Groningen)

Prof.dr. R.S. Reneman

Financial support by the Netherlands Heart Foundation for the publication of this thesis is gratefully acknowledged. 


\section{CONTENTS}

1. Introduction 7

2. Historical overview 9

3. Semiselective angiography of the internal mammary artery as a preparation for coronary bypass surgery 25

4. Grafting with the internal mammary artery: correlation between preoperative angiography and intraoperative findings 29

5. Internal mammary artery bypass grafting in left main stenosis $\quad 35$

6. Unstable angina pectoris and internal mammary artery bypass grafting 41

7. Combined two-dimensional and Doppler sonographic examination of internal mammary grafts from the supraclavicular fossa $\quad 47$

8. Doppler sonographic examination of the internal mammary artery graft. Comparison of supraclavicular and high intercostal signals 55

9. Doppler sonographic examination of the internal mammary artery graft. Influence of exercise. 61

Conclusions and summary 67

Schlussfolgerungen und Zusammenfassung $\quad 69$

Conclusies en samenvatting 71

Curriculum vitae $\quad 73$

Tot slot $\quad 75$ 


\section{INTRODUCTION}

Coronary atherosclerosis has been present for many centuries (1) and is in our society a leading cause of morbidity and mortality (2). Treatment includes drug therapy, interventional catheterization techniques with mainly percutaneous transluminal coronary angioplasty, and surgical coronary artery revascularization. During the last 25 years coronary artery bypass surgery has gone through tremendous developments, both in technique and number of operations. One of the areas of study has been the identification of the most suitable bypass vessel with emphasis upon long-lasting patency. This resulted in the use of the internal mammary artery as the preferred graft material, because of its durability and better patient survival.

This thesis discusses several aspects of the use of the internal mammary artery graft during coronary bypass surgery: Chapter 2 gives a historical overview of the use of the internal mammary artery for myocardial revascularization. The incidence of atherosclerotic narrowing in the internal mammary artery is said to be low but angiographic studies are rare. We therefore decided to perform a preoperative angiographic investigation, described in chapter 3 . The relation of preoperative angiography to intraoperative findings is unknown. The results of such a study are reported in chapter 4 . Whether a mammary artery bypass graft should be used in specific critical situations is a matter of debate. Chapters 5 and 6 describe the outcome of the use of the internal mammary artery graft in left main coronary artery stenosis and unstable angina pectoris. Postoperative non-invasive investigation of graft function by using the Doppler technique is relatively new. We try to evaluate this technique in comparing a grafted vessel to a nonbypassed mammary artery (chapter 7 ), in comparing the influence of different transducer positions on these measurements (chapter 8) and in comparing the influence of exercise on flow in the internal mammary artery graft in chapter 9 . Summaries in the english, german and dutch language are found at the end of this thesis. 


\section{Literature}

1 Long AR. Cardiovascular renal disease: report of a case of three thousand years ago. Arch Pathol 1931;12:92-94.

2 Centraal Bureau voor de Statistiek. Vademecum gezondheidsstatistiek nederland 1993. 's Gravenhage, SDU 1993 p 89, 104. 


\section{HISTORICAL OVERVIEW}

The development of coronary artery surgery

The surgical treatment of coronary artery disease began with cardiac denervation (1). This was followed by attempts at myocardial revascularization by sewing the omentum majus on the epicardium, obstructing venous drainage and by the application of irritating agents (phenol, talc, asbestos) to the epicardium. This was all done in the hope that collateral vessels to the myocardium would develop. Even ligature (!) of the distal part of the internal mammary artery was suggested, so that flow through the pericardial branches would increase (2-8).

The first more physiologic solution to the problem of myocardial revascularization was developed by Vineberg (9): implantation of the internal mammary artery deep in the myocardium, in the flow bed of a narrowed coronary artery. This approach resulted in the development of new collateral vessels, that communicated with the distal branches of the narrowed coronary artery. The technique was first applied to laboratory animals and later in human patients $(9,10)$.

The development of coronary angiography (11) opened the possibility to localize coronary artery stenoses and to quantify their severity, a necessary step in the establishment of adequate coronary artery surgery. This was followed by direct approaches to the narrowed coronary artery like the application of a venous or pericardial patch to a narrowed vessel, resection of an obstructed part of a coronary artery with interpositioning of a venous graft or mechanical endarterectomy (12-14). In 1964 De Bakey (15) et al anastomosed an autologous vein between the aorta and the distal part of a narrowed coronary artery. The internal mammary artery was applied using a similar procedure, first by Kolesov, later by Green $(16,17)$.

During the last decades coronary artery bypass surgery has become one of the most frequently performed surgical interven- 


\begin{tabular}{llcc}
\hline YEAR & CABG & LIMA & LIMA / CABG \\
\cline { 2 - 4 } & $\mathrm{n}$ & $\mathrm{n}$ & $\%$ \\
\hline 1987 & 111 & 69 & 62 \\
1988 & 118 & 78 & 66 \\
1989 & 134 & 107 & 80 \\
1990 & 135 & 118 & 87 \\
1991 & 140 & 120 & 86 \\
1992 & 114 & 103 & 90 \\
\hline
\end{tabular}

Percentage of the left internal mammary artery used during coronary bypass surgery in patients of the Maasland Hospital Sittard, operated upon in the Academic Hospital Maastricht in the years 1987 to 1992.

Abbreviations: $\mathrm{LIMA}=$ left internal mammary artery, $\mathrm{CABG}=$ coronary artery bypass surgery.

tions, being about $80 \%$ of all cardiosurgical procedures. In the Netherlands about 9.175 coronary bypass operations were performed in 1992. (Begeleidingscommissie hartchirurgie Nederland, unpublished data). It is not only performed as a palliative therapy in patients with angina pectoris but also increases survival in certain groups of patients (18-20).

\section{The internal mammary artery as a coronary artery bypass graft}

Apart from autologous saphenous vein grafts, the internal mammary artery is currently commonly used as a bypass vessel. The latter is used especially as a bypass graft to the left anterior descending artery or its first diagonal branch. Reasons for the increasing use of the internal mammary artery as a bypass vessel include evidence that it lacks atherosclerosis, has significantly higher patency rates than saphenous vein grafts (which show progressive intimal hyperplasia and atherosclerosis ultimately leading to graft closure) and therefore gives better patient survival $(15,21,22)$. In patients of our own hospital who are operated upon in the Academic Hospital of Maastricht, the left internal mammary artery was used during the last six years in about $80 \%$ of all coronary bypass procedures. As documented in table I there is still 
a steady increase, with the left internal mammary artery being used in 1992 in about $90 \%$ of all bypass operations (B. Pluym, unpublished data).

\section{Anatomy of the internal mammary artery}

In $98 \%$ of cases the internal mammary artery arises from the anteroinferior aspect of the first part of the subclavian artery.

Origin of the internal mammary artery from the third part of the subclavian artery occurs in $1-2 \%$ of patients. The vessel runs downwards and medially to enter the thurax behind the first costal cartilage and descends 1.5 to 2 centimeters from the lateral sternal border. In $50 \%$ of cases it bifurcates at the level of the sixth intercostal space, in the other $50 \%$ this occurs one intercostal space higher or lower. Of surgical importance is a high bifurcation at the third or fourth intercostal cartilage level, occurring in $2 \%$ of cases. The terminal branches are the musculophrenic and superior epigastric arteries. Side branches of the internal mammary artery are: the mediastinal, thymic and bronchial branches, the pericardiophrenic artery, the sternal, perforating and mammary branches, the lateral costal branch and the anterior intercostal branches (23).

The internal mammary artery is an elastic artery with a wall composed of elastic and collagen lamellae held together by interconnecting bridges interspersed with smooth muscle cells. It is lined by a very well defined internal elastic membrane which only has small perforations (fenestrae) and supports a thin layer of endothelial cells (24-26).

\section{Surgical procedure}

The internal mammary artery is mobilized and its side branches are ligated. The vessel is then placed intrapleurally, parallel to the phrenic nerve. After entering the mediastinal pericardium an anastomosis to the left anterior descending artery is made. Usually only the left internal mammary artery is used in this fashion but sequential internal mammary artery grafting, free grafting and bilateral grafting is also possible.

\section{Follow-up of mammary artery grafts}

Internal mammary arteries are rarely affected by atherosclerosis (25-28), but occasional reports of significant atherosclerotic dis- 


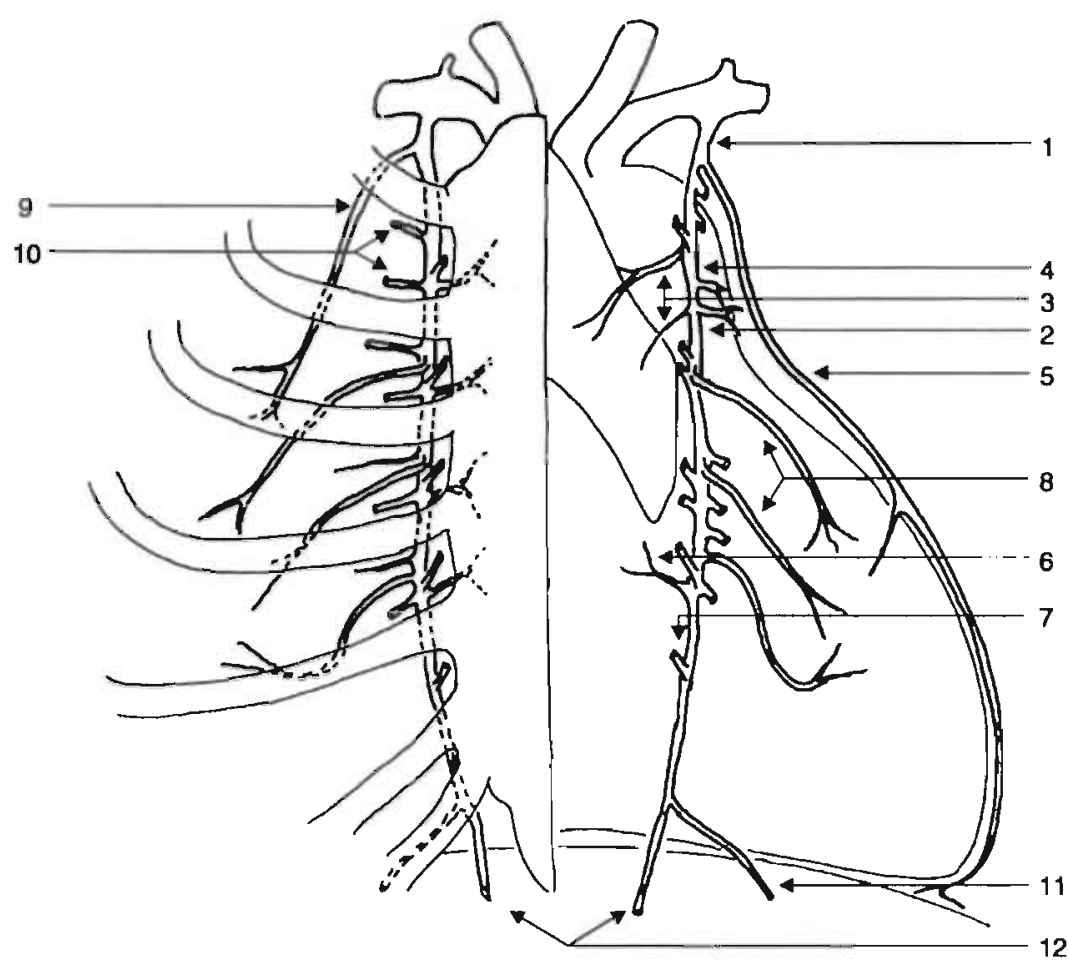

Figure 1: Anatomy of the internal mammary artery, the course of the vessel and its side branches in relation to the heart and other anatomical structures. Adapted from: Feneis $H$., pocket atlas of human anatomy. Thieme publishers, Stuttgart 1976.

1 A. mammaria interna $2 \mathrm{Rr}$. mediastinales $3 \mathrm{Rr}$. Thymici $4 \mathrm{Rr}$. bronchiales 5 A. pericardiacophrenica $6 \mathrm{Rr}$. sternales $7 \mathrm{Rr}$. perforantes $8 \mathrm{Rr}$. mammarii $9 \mathrm{R}$. costalis lateralis $10 \mathrm{Rr}$. intercostales anteriores $11 \mathrm{~A}$. musculophrenica 12 A. epigastrica superior

ease have appeared $(29,30)$. Why atherosclerotic changes are rare is unclear. Possible factors are the thin intima in the internal mammary artery or the scanty presence of smooth muscle cells in the thin-walled media (31). The fact that atherosclerotic disease seldom occurs in the internal mammary artery is confirmed by reports of PTCA procedures of this vessel that mostly concern the distal anastomosis (32).

In venous grafts early graft occlusion is often due to thrombosis and late graft occlusion is commonly attributed to intimal proliferation and superimposed thrombosis. Progressive atherosclerosis is supposed to be the main cause of graft occlusion after one year (33). 
Data from the literature show that after a mean follow-up of 36 months the patency rate for internal mammary artery grafts is 96 per cent.

The patency rate for saphenous vein grafts at a mean follow-up period of 39 months is about 77 per cent. At 7 to 10 years after surgery, internal mammary artery graft patency has been shown to range from 85 to 95 per cent as compared to 50 to 60 per cent in saphenous vein grafts (21,34-37).

Patients with internal mammary artery grafts have a lower risk of late myocardial infarction, and a better survival rate at 10 years than patients who have saphenous vein grafts $(21,35,38-40)$. This difference in clinical outcome is attributed to the use of internal mammary artery grafts, but bias because of selection of patients and coronary arteries can not be excluded. No prospective study to answer this question has yet been published.

\section{Limitations of the internal mammary artery graft}

There are some possible disadvantages and limitations in the use of internal mammary grafts: Preparation of the internal mammary artery for grafting requires time consuming delicate retrosternal dissection. This may limit its use in patients with unstable angina pectoris where operating time is a critical factor. Geha (41) stated that coronary revascularization with internal mammary artery grafts can be achieved with low risk, even in unstable angina, but in a later report he said that the use of an internal mammary artery is not advised in unstable patients, as did others $(42,43)$.

Anomalies: by preoperative angiography Bauer (44) found surgically significant anomalies in $26 \%$ of 459 vessels, such as common origin of another large artery (the thyreocervical and costocervical trunk), large side branches, tortuosity, atypical course or origin and atherosclerotic lesions. Modification of surgical strategy, i.e. not using the internal mammary artery, was necessary in $4 \%$ of patients. An additional advantage of preoperative semi-selective angiography would be to exclude occasional aortic or subclavian lesions proximal to the internal mammary artery. Routine preoperative angiography of the internal mammary artery is, however, not considered to be necessary by most cardiac surgeons (45). This is in contrast to the situation of a redo coronary artery bypass operation, because the internal mammary artery may be occluded related to the prior surgery (46). This may also be the case in congenital chest wall deformities, chest wall trauma and previous irradiation therapy. 


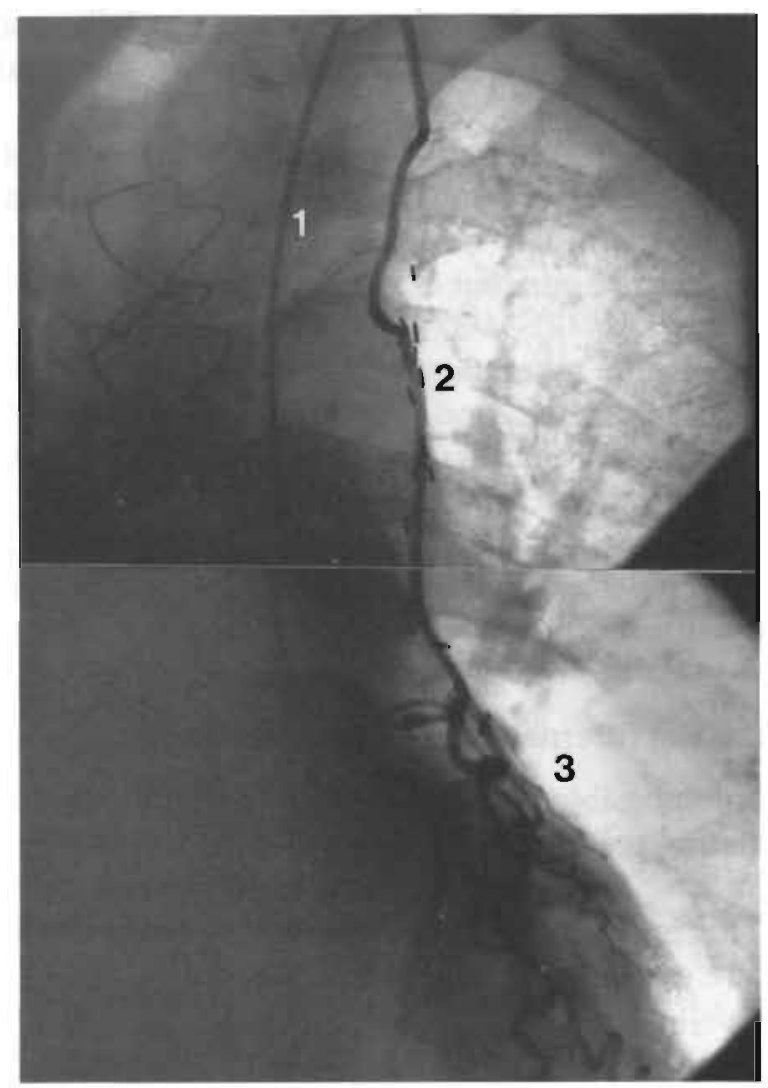

Figure 2: Angiography of an internal mammary artery graft anastomosed to the left anterior descending artery.

1 angiography catheter 2 internal mammary artery 3 left anterior descending artery

The artery must be of adequate size and flow. Size is a problem because of the limited extension of the vessel and its limited number, making multiple grafting difficult.

Under experimental conditions internal mammary artery grafts show lower flows than saphenous vein grafts $(47,48)$. Barner $(49)$ measured flow in the internal mammary artery using the electromagnetic flow probe after discontinuation of cardiopulmonary bypass and found basal flows equal to but peak flows significantly lesser as compared to venous grafts. Intraoperative measurements of graft flow is recommended by some authors $(50,51)$. However, the flow problem seems only relevant in the direct postoperative 


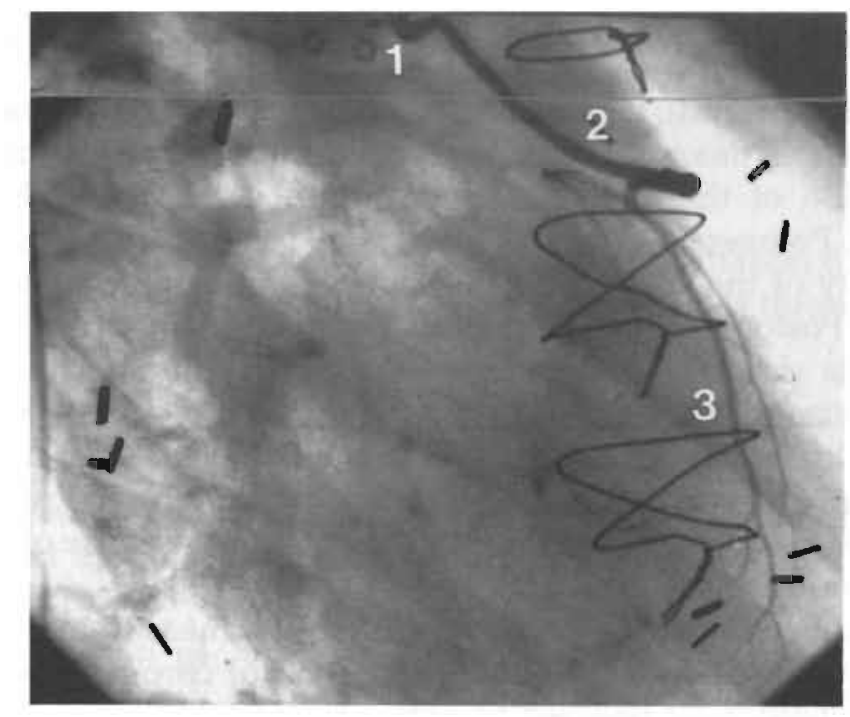

Figure 3: Angiography of a reversed saphenous vein graft with a distal anastomosis to the circumflex artery. 1 angiography catheter 2 reversed saphenous vein graft 3 circumflex artery

period as the internal mammary artery graft adapts to an increase in myocardial blood demand by an increase in luminal diameter $(52,53)$.

Postoperative problems of increased bleeding, phrenic nerve injury, mediastinal infection and arm paresis or paresthesia are complications attributed to internal mammary artery grafting, but they are uncommon if meticulous technique is used $(54,55)$. This also holds for the elderly patient (56).

There is some discussion on the use of the internal mammary artery in high-risk patients such as unstable angina, PTCA-failure and left main stenosis in whom high graft flows in the direct postoperative situation are desirable, although this may only be relevant to patients with critical ischemia at the time of operation. Spasm of the internal mammary artery causing profound hemodynamic and electrocardiographic consequences has been reported (57). Vasopressors and inotropic agents are commonly used in the early postoperative period and the possibility of constriction of the vascular smooth muscle of the internal mammary artery graft with reduced flow after administration of these agents is a concern. 


\section{Evaluation of graft function}

Evaluation of graft function is usually done by contrast angiography i.e. by invasive techniques. Non-invasive, ultrasound investigation of the mammary artery graft is an investigational method. Preoperative duplex imaging is performed to asses the suitability of the vessel, and shows a predominant systolic flow pattern. Postoperative examination is done to evaluate graft function. This shows a flow pattern clearly different from the nongrafted vessel with a more diastolic predominant curve (58-65).

Little is known about the changes in the Doppler signal in scanning from different positions (supraclavicular, high and low intercostal spaces). Neither has the influence of exercise or use of drugs been investigated.

Even intracoronary Doppler flow velocity measurements are nowadays possible, allowing investigation of coronary flow reserve, which could be used to support a possible indication for angioplasty. Direct evaluation of the effects of vascular interventions may also prove useful (66-70). 


\section{Literature}

1 Jonnesco T. Angine de poitrine guérie par la résection du sympathique cervico-thoracique. Bull Acad Med (Paris) 1920;84:93-102.

2 Moritz AR, Hudson CL, Orgain ES. Augmentation of the extracardiac anastomoses of the coronary arteries through pericardial adhesions. J exp Med 1932;56:927-931.

3 O'Shaugnessy L. Surgical treatment of cardiac ischemia. Lancet 1937;1:185-194.

4 Stanton E, Batiuchok W, Leiter E. Revascularization of the heart by graft of systemic artery into coronary sinus. JAMA 1948;137:436-442.

5 Harken DE, Black H, Dickson JF, Wilson HE. De-epicardialization: a simple, effective surgical treatment for angina pectoris. Circulation 1955;12:955-962.

6 Thompson SA, Plachta A. Fourteen years experience with cardiopexie in treatment of coronary artery disease. J Thorac Surg 1957;27:64-72.

7 Gorelik AN. Critical analysis of cardiopericardiomyopexie with eight year follow-up. J Int Coll Surgeons 1957;28:401-408.

8 Battezzati M, Tagliaferro A, De Marchi G. La legatura delle due arterie mammarie interne nei disturbi di vascolarizzazione del miocardio. II Minerva med 1955;46:1178-1181.

9 Vineberg A. Development of anastomosis between the coronary vessels and a transplanted internal mammary artery. Can Med Assoc J 1946;55:117-119.

10 Vineberg A, Walker J. The surgical treatment of coronary artery disease by internal mammary artery implantation. Dis Chest 1964;45:190-206.

11 Sones jr, FM, Shirey EK. Collateral arterial channels in the living human with coronary artery disease. Circulation 1960;22:815-816 (Abstract).

12 Senning A. Strip grafting in coronary arteries: report of a case. J Thorac Cardiovasc Surg 1961;41:542-549.

13 Favalora R. Direct and indirect coronary surgery. Circulation 1972;46:1197-1207. 
14 Effler DB. Myocardial revascularization surgery since 1945. Its evolution and impact. J Thorac Cardiovasc Surg 1976;72:823828.

15 De Bakey M, Garrett HE, Dennis EW. Aorto-coronary bypass with saphenous vein graft. Seven-year follow-up. JAMA 1973;223:792-794.

16 Kolesov VI. Mammary artery-coronary artery anastomosis as a method of treatment for angina pectoris. J Thorac Cardiovasc Surg 1967;54:535-544.

17 Green GE. Internal mammary artery-to-coronary artery anastomosis. Ann Thorac Surg 1972;14:260-271.

18 Campeau L, Corbara F, Crochet D, Petitclerc R. Left main coronary artery stenosis, the influence of aortocoronary bypass surgery on survival. Circulation 1978;57:1111-1115.

19 Chaitman BR, Fisher LD, Bourassa MG, Davis K, Rogers WJ, Maynard C, Tyras DH, Berger RL, Judkins MP, Ringqvist I, Mock MB, Killip T. Effect of coronary bypass surgery on survival patterns in subsets of patients with left main coronary artery disease. Am J Cardiol 1981;48:765-777.

20 Gersh BJ, Califf RM, Loop FD, Akins CW, Pryor DB, Takaro TC. Coronary bypass surgery in chronic stable angina. Circulation 1989;79(suppl I):I-46-59.

21 Loop FD, Lytle BW, Cosgrove DM, Stewart RW, Goormastic M, Williams GW, Golding LAR, Gill CC, Taylor PC, Sheldon WC, Proudfit WL. Influence of the internal mammary artery graft on 10-year survival and other cardiac events. N Engl J Med 1986;314:1-6.

22 Spencer FC. The internal mammary artery: the ideal coronary bypass graft? N Engl J Med 1986;314:50-51.

23 Walls EW. The blood vascular and lymphatic systems. In: Romanes A ed. Cunningham's textbook of anatomy London: Oxford university press $1972,878-879$.

24 Sims FH. Discontinuities in the internal elastic lamina: a comparison of coronary and internal mammary arteries. Artery 1985;13:127-143.

25 Sims FH. A comparison of coronary and internal mammary arteries and implications of the results in the etiology of atherosclerosis. Am heart J 1983;105:560-566. 
26 van Son AM, Smedts F, Vincent JG, van Lier JJ, Kubat K. Comparative anatomic studies of various arterial conduits for myocardial revascularization. J Thorac Cardiovasc Surg 1990;99:703-707.

27 Mestres CA, Rives A, Igual A, Vehi C, Murtra M. Atherosclerosis of the internal mammary artery. Histopathological analysis and implications on its results in coronary artery bypass graft surgery. Thorac Cardiovase Surgeon 1986;34:356358.

28 Singh RN. Atherosclerosis and the internal mammary arteries. Cardiovasc Intervent Radiol 1983;6:72-77.

29 Frazier BL, Flemma RJ, Tector AJ, Korns ME. Atherosclerosis involving the internal mammary artery. Ann Thorac Surg 1974;18:305-307.

30 Rainer WG, Sadler TR, Liggett MS. Internal mammary arteriography prior to coronary artery bypass surgery. Chest 1973;64:523-524.

31 Ferro M, Conti M, Novero D, Micca FB, Palestro G. The thin intima of the internal mammary artery as the possible reason for freedom from atherosclerosis and success in coronary bypass. Am Heart J 1991;4:1192-1195.

32 Dimas AP, Arora RR, Whitlow PL, Hollman JL, Franco I, Raymond RE, Dorosti K, Simpfendorfer CC. Percutaneous transluminal angioplasty involving internal mammary artery grafts. Am Heart J 1991;122:423-429.

33 Fuster V, Badimon L, Badimon J, Adams PC, Turitto V, Chesebro JH. Drugs interfering with platelet functions: mechanisms and clinical relevance. In: Verstraete $M$, Vermylen J, Lijnen R, Arnout J, eds. Thrombosis and haemostasis 1987. Leuven: Leuven University Press, 1987:349-418.

34 Tector AJ, Schmahl TM, Canino VR. The internal mammary artery graft: the best choice for bypass of the diseased left anterior descending coronary artery. Circulation 1983; 68(suppl.II):II-214-217.

35 Grondin CM, Campeau L, Lesperance J, Enjalbert M, Bourassa MG. Comparison of late changes in internal mammary and saphenous vein grafts in 2 consecutive series of patients 10 years after operation. Circulation 1984;70(suppl.I):I-208-212. 
36 Barner HB, Standeven JW, Reese J. Twelve year experience with internal mammary artery for coronary artery bypass. J Thorac Cardiovasc Surg 1985;90:668-675.

37 Bourassa MG, Fisher LD, Campeau L. et al. Long-term fate of bypass grafts: The Coronary Artery Surgery Study (CASS) and the Montreal Heart Institute experiences. Circulation 1985;72(suppl. V):V-71-78.

38 Singh RN, Sosa JA, Green GE. Internal mammary artery versus saphenous vein graft. Comparative performance in patients with combined revascularisation. Br Heart J 1983; 50:48-51.

39 Loop FD, Irarrazaval MJ, Bredee JJ, Siegel W, Taylor PC, Sheldon WC. Internal mammary artery graft for ischemic heart disease. Effect of revasularization on clinical status and survival. Am J Cardiol 1977;39:516-522.

40 Lyttle BW, Kramer JR, Golding LR, Cosgrove DM, Borsh JA, Goormastic M, Loop FD. Young adults with coronary atherosclerosis: 10 year results of surgical myocardial revascularization. J Am Coll Cardiol 1984;4:445-453.

41 Geha AS, Krone RJ, McCormick JR, Baue AE. Selection of coronary bypass. Anatomic, physiological and angiographic considerations of vein and mammary artery grafts. J Thor Cardiovasc Surg 1975;70:414-431.

42 Geha AS, Baue AE. Early and late results of coronary revascularization with saphenous vein and internal mammary artery grafts. Am J Surg 1979;137:456-463.

43 Grondin CM, Campeau L, Thornton JC, Engle JC, Cross FS, Schreiber $\mathrm{H}$. Coronary artery bypass grafting with saphenous vein Circulation 1989;79(suppl I):I-24-29.

44 Bauer EP, Bino MC, von Segesser LK, Laske A, Turina MJ. Internal mammary artery anomalies. Thorac Cardiovasc Surgeon 1990;38:312-315.

45 Cron JP, Adolph WL, Alfandari JP, Baud F, Beuzelin JP, Bonnemazou A, Gepner J, Nigot G, Piroelle Y. L'artère mammaire interne gauche. La presse médicale, 1987;16:427-430.

46 Feit A, Reddy CV, Cowley C, Ibrahim B, Zisbrod Z. Internal mammary artery angiography should be a routine component of dingnostic coronary angiography. Cathet Cardiovasc Diagn 1992;25:85-90. 
47 Dobrin P, Canfield T, Moran J, Sullivan H, Pifarre R. Coronary artery bypass; the physiological basis for differences in flow with internal mammary artery and saphenous vein grafts. J Thorac Cardiovasc Surg 1977;74:445-454.

48 Flemma RJ, Singh HM, Tector AJ, Lepley D, Frazier BL. Comparative hemodynamic properties of vein and mammary artery in coronary bypass operations. Ann Thorac Surg 1975;20:619-627.

49 Barner HB. Blood flow in the internal mammary artery. Am Heart J 1973;86:570-571.

50 Green GE. Rate of blood flow from the internal mammary artery. Surgery 1971;70:809-813.

51 Huddleston CB, Stoney WJ, Thomas CS et al. Internal mammary artery grafts: technical factors influencing patency. Ann Thorac Surg 1968;42:543-549.

52 Ivert T, Huttunen K, Landou C, Björk VO. Angiographic studies of internal mammary artery grafts 11 years after coronary artery bypass grafting. J Thorac Cardiovasc Surg 1988;96:1-12.

53 Hanet C, Schroeder E, Michel X, Cosyns J, Dion R, Verhelst R, Wijns $W$. Flow-induced vasomotor response to tachycardia of the human internal mammary artery and saphenous vein grafts late following bypass surgery. Circulation 1991;84(suppl III):III-268-274.

54 Green GE. Use of internal thoracic artery for coronary artery grafting. Circulation 1989;79(suppl I):I-30-33.

55 Cosgrove DM, Loop FD, Lytle BW, Goormastic M, Stewart RW, Gill CC, Golding LR. Does mammary artery grafting increase surgical risk? Circulation 1985;72(suppl II):II-170-174.

56 Fleury JP, Paulis R de, Chevret S, Subayi JB, Oroudji M, Menasche Ph, Bloch G, Piwnica A. Is the internal mammary artery an acceptable graft in the elderly patients with left main coronary artery disease? Eur J Cardiothorac Surg 1992;6:475-478.

57 Fischell TA, McDonald TV, Grattan MT, Miller DC, Stadius ML. Occlusive coronary artery spasm as a cause of acute myocardial infarction after coronary bypass grafting. N Engl J Med 1989;320:400-401. 
58 de Bono DP, Samani NJ, Spyt T, Hartshorne T, Trush H, Evans $\mathrm{DH}$. Transcutaneous uitrasound measurements of flow in internal mammary to coronary artery grafts. Eur Heart J 1991;12(Suppl):141 (Abstract).

59 de Bono DP, Samani NJ, Spyt T, Hartshorne T, Trush H, Evans $\mathrm{DH}$. Transcutaneous ultrasound measurement of blood-flow in internal mammary artery to coronary artery grafts. Lancet 1992;339:379-381.

60 Canver CC, Ricotta JJ, Bhayana JN, Fiedler RC, Mentzer RM. Use of duplex imaging to assess suitability of the internal mammary artery for coronary artery surgery. J Vasc Surg 1991;13:294-301.

61 Ciccone M, Federici A, di Michele L, Marchese A, Chiddo A, Rizzon P. Doppler continuous-wave analysis of grafted mammary artery as a non-invasive technique for static and dynamic assessment of coronary flow in man. Eur J Appl Physiol 1990;61:338-343.

62 Fusejima K, Takahara Y, Sudo Y, Murayama H, Masuda Y, Inagaki $Y$. Comparison of coronary hemodynamics in patients with internal mammary artery and saphenous vein coronary artery bypass grafts: a noninvasive approach using combined two-dimensional and Doppler echocardiography. J Am Coll Cardiol 1990;15:131-139.

03 Sons H, Becker T, Marx R, Lösse B, Schulte HD, Bircks W. Postoperative ultrasonic duplex scanning of the internal mammary artery. Eur Heart J 1989;10 (Suppl):304 (Abstract).

64 Canver CC, Fiedler RC, Hoover EL, Ricotta JJ, Mentzer RM. Noninvasive assessment of internal thoracic artery for reoperative coronary artery surgery. J Cardiovasc Surg 1992;33:534-537.

65 Takayama T, Suma H, Wanibuchi Y, Furuta S, Tohda E, Yamashita S, Matsunaka T. Doppler miniprobe to measure arterial graft flow in coronary artery bypass grafting. Ann Thorac Surg 1991;52:322-324.

66 Ofili EO, Labovitz AJ, Kern MJ. Coronary flow velocity dynamics in normal and diseased arteries. Am J Cardiol 1993;71:3D-7D.

67 White CW. Clinical applications of Doppler coronary flow resterve measurements. Am J Cardiol 1993;71:10D-16D. 
68 Kern MJ, Donohue TJ, Aguirre FV, Bach RG, Caracciolo EA, Ofili E, Labovitz AJ. Assessment of angiographically intermediate coronary artery stenosis using the Doppler flowire. Am J Cardiol 1993;71:26D-33D.

69 Segal J. Applications of coronary flow velocity during angioplasty and other coronary interventional procedures. Am J Cardiol 1993;71:17D-25D.

70 Serruys PW, di Mario C, Meveneau N, de Jaegere P, Strikwerda $\mathrm{S}$, de Feyter PJ, Emanuelsson H. Intracoronary pressure and flow velocity with sensor-tip guidewires: a new methodologic approach for assessment of coronary hemodynamics before and after coronary interventions. Am J Cardiol 1993;71:41D53D. 



\section{SEMISELECTIVE}

ANGIOGRAPHY OF THE

INTERNAL MAMMARY

ARTERY AS A

PREPARATION FOR

CORONARY BYPASS

SURGERY

Rudolf Krijne, MD, Mario C.-H.K. Deng, MD,

Karl-Wilhelm Heinrich, MD, Hermann Sons, MD, and Arno Krian, MD

From the Departments of Cardiology and Cardiac Surgery,

Herzzentrum Kaiser Wilhelm Krankenhaus, Gerrickstrasse 21, 4100 Duisburg, West-Germany.

American Journal of Cardiology, 1990;66:377-378. 
Internal mammary artery grafting in coronary artery bypass surgery has resulted in increased long-term patency and improved survival compared to venous bypass grafting. Angiography of the mammary arteries before bypass surgery is considered to be superfluous because they are rarely affected by atherosclerosis (1). There are, however no data on how often an internal mammary artery graft is intraoperatively rejected because of insufficient sluggish flow due to atherosclerosis. Early postoperative graft failure is said to be mainly related to technical errors (2). To establish the frequency of atherosclerotic changes in the subclavian and internal mammary arteries among our patients, we performed semiselective angiography on both mammary arteries during cardiac catheterization in candidates for bypass surgery.

One hundred five consecutive patients ( 87 men and 18 women) aged $35-80$ years (median 58 ) were studied. Sixty-five patients $(62 \%)$ had 3-vessel disease, $25(24 \%)$ had 2-vessel disease and 15 (14\%) had 1-vessel disease. In all patients semiselective angiography of both mammary arteries, performed with a standard $5 \mathrm{Fr}$ right Judkins diagnostic catheter, complemented the coronary artery procedure. Ten $\mathrm{ml}$ of undiluted contrast medium was injected manually with the catheter tip as near as possible to the urigin of the internal mammary artery. Only posteroanterior views were used, documented on $35-\mathrm{mm}$ cinefilm. Significant atherosclerosis was defined as a diameter reduction of $\geq 50 \%$. In 13 patients the imaging quality of the right mammary artery was insufficient; thus, 105 left and 92 right vessels were studied. We saw a stenosis in the proximal part of the internal mammary artery in only 1 patient $(0.95 \%)$, a 43 -year old woman with lipoatrophy. There were no significant subclavian artery stenoses proximal to the internal mammary artery, and only 2 patients $(1.9 \%)$ had stenoses distal to the origin of the mammary arteries.

Routine postmortem studies $(4,5)$ show $\geq 50 \%$ narrowing of the lumen in 0 to $5 \%$ of the cases. Routine preoperative angiography of the internal mammary arteries has seldom been done. The only reported study (6) of patients with coronary artery disease showed a $2 \%$ incidence of atherosclerosis in the mammary arteries and a $4 \%$ incidence of atherosclerosis in the subclavian arteries. Our results showed an even lower incidence of these pathologic changes. Even in older patients, in whom atherosclerosis is usual- 
ly advanced, no pathology of the mammary artery was found. It seems that routine preoperative angiography of the mammary artery is indeed unnecessary. 


\section{Literature}

1 Cron JP, Adolf WL, Alfandari JP, Baud F, Beuzelin JP, Bonnemazou A, Gepner J, Piroelle Y. L'artère mammaire interne gauche. La Presse Médicale 1987;16:427-430.

2 Ivert $\mathrm{T}$, Huttunen $\mathrm{K}$, Landou $\mathrm{C}$, Björk VO. Angiographic studies of internal mammary artery grafts 11 years after coronary artery bypass grafting. J Thorac Cardiovasc Surg 1988;96:1-12.

3 Shimshak TM, Giorgi LV, Johnson WL, McConahay DR, Rutherford BD, Ligon R, Hartzler GO. Application of percutaneous transluminal coronary angioplasty to the internal mammary artery artery graft. JACC 1988;12:1205-1214.

4 Sims FH. A comparison of coronary and internal mammary arteries and implications of the results in the etiology of atherosclerosis. Am Heart J 1983;105:560-566.

5 Kay Hr, Korns ME, Flemma RJ, Tector AJ, Lepley D. Atherosclerosis of the internal mammary artery. Ann Thorac Surg 1976;21:504-507.

6 Singh RN. Atherosclerosis and the internal mammary arteries. Cardiovasc Intervent Radiol 1983;6:72-77. 
GRAFTING WITH THE INTERNAL MAMMARY ARTERY: CORRELATION BETWEEN PREOPERATIVE ANGIOGRAPHY AND INTRAOPERATIVE FINDINGS

Ruud Krijne, Mario C.-H.K. Deng, Barbara Stegmann, Karl-Wilhelm Heinrich, Hermann Sons and Arno Krian. 


\section{Abstract}

No data exist on the relation between angiography of the internal mammary artery and intraoperative findings during bypass surgery. We studied 47 consecutive patients and found no atherosclerotic changes. Intraoperatively, however, 4 left internal mammary arteries were judged unsuitable for grafting. No relation could be found to the diameter of the vessel as judged angiographically. Possible causes of unsuitability are discussed.

\section{Key words}

Internal mammary artery; Angiography; Bypass surgery

\section{Introduction}

Angiography of the internal mammary artery as a preparation for coronary bypass surgery is seldom done, because this vessel is affected by significant atherosclerosis in only $1-2 \%$ of candidates for coronary artery bypass surgery (1). No data exist, however, on how often an internal mammary is judged intraoperatively to be unsuitable for grafting because of insufficient flow. Moreover it is unknown whether this unsuitability is caused by atherosclerosis of the artery or is due to other factors. Failure of the graft in the early postoperative period is reported to be mainly related to technical errors $(2,3)$. We studied the intraoperative findings in a group of patients who had shown no abnormalities in preoperative angiography of the internal mammary artery.

\section{Methods}

47 Consecutive patients, 41 men and 6 women, aged 36 to 76 years (mean 57.9) were studied. In all of them, semiselective angiography of the left internal mammary artery performed at the end of the coronary angiography excluded atherosclerotic changes. The diameter of the internal mammary artery at its origin, and at the level of the fifth intercostal cartilage (the expected site of anastomosis with the left anterior descending artery), was compared to that of the catheter and expressed in millimeters. Grafting was then scheduled as part of the surgical revascularization procedure. Recordings of blood pressure were taken at the moment that the internal mammary artery was judged suitable or unsuitable for grafting. 


\section{Results}

47 Left mammary arteries were prepared for grafting. In 4 cases (8.5\%), all males, ages 35, 61, 65 and 67 years, the internal mammary artery was judged intraoperatively to be of too small a calibre, and showed too little flow, to be used as a graft to the left anterior descending artery. Retrospectively, we compared the angiographic data of these patients with the other 43 internal mammary arteries which were found suitable at operation for bypass grafting.

The diameter of the internal mammary artery at its origin showed no differences in the two groups $(1.6,1.6,1.7$ and $3.4 \mathrm{~mm}$ versus $1.7 \pm 0.9 \mathrm{~mm})$, nor was this so at the level of the fifth costal cartilage $(1.2,1.3,1.3$ and $1.4 \mathrm{~mm}$ versus $1.4 \pm 0.6 \mathrm{~mm})$. Blood pressure in the rejected cases (120-140/80-90 $\mathrm{mm} \mathrm{Hg}$ ) was not different from the rest of the group $(123 \pm 31 / 71 \pm 20 \mathrm{~mm} \mathrm{Hg})$.

\section{Discussion}

Routine preoperative angiography of the internal mammary arteries is seldom done and to the best of our knowledge no correlation to intraoperative findings has been published. In some cases, the availability of a mammary artery can be relevant, for instance in patients with extensive varicose veins or previous bypass operation. In our group of patients, a surprisingly high percentage $(8.5 \%)$ of the internal mammary arteries was judged intraoperatively to be unsuitable for bypass grafting to the left anterior descending artery. No atherosclerotic changes were seen on preoperative angiography, and no differences could be found as to calibre either proximally or at the level of the fifth costal cartilage. The cause of the unsuitability, therefore, remains unclear. Technical reasons could exist, causing spasm of the vessel, for instance, but 2 of the patients whose artery was rejected were given papaverine intraoperatively without result. Another cause could be damage to the vessel during preparation, but no such damage was reported in the operation protocol. No measurements of flow or diameter were performed intraoperatively, but the decision not to use the mammary artery as material for bypass is one which depends mainly on clinical judgment. It may have been possible to use the vessels judged to have poor flow for grafting to a diagonal branch of the left anterior descending artery, but this was not analyzed.

In any case, it seems that reasons other than atherosclerosis are more often the cause for unsuitability of the internal mammary 
artery as a bypass graft. Morover, there seems to be no correlation between this unsuitability and the diameter of the vessel as judged angiographically.

Preoperative angiography seems not to be a useful investigation in planning revascularization procedures. Larger series are needed to confirm our findings. Other methods, such as rapid computerized tomographic scanning, should also be investigated, as they may be more useful in providing an estimate of flow within the internal mammary artery. 


\section{Literature}

1 Singh RN. Atherosclerosis and the internal mammary arteries. Cardiovasc Intervent Radiol 1983;6:72-77.

2 Ivert $\mathrm{T}$, Huttunen $\mathrm{K}$, Landou $\mathrm{C}$, Björk VO. Angiographic studies of internal mammary artery grafts 11 years after coronary artery bypass grafting. J Thorac Cardiovasc Surg 1988;96:1-12.

3 Shimshak TM, Giorgi LV, Johnson WL, McConahay DR, Rutherford BD, Ligon R, Hartzler GO. Application of percutaneous transluminal coronary angioplasty to the internal mammary artery graft. J Am Coll Cardiol 1988;12:1205-1214. 



\section{INTERNAL MAMMARY ARTERY BYPASS GRAFTING IN LEFT MAIN STENOSIS}

Reinhard Höltgen, Ruud Krijne, Karl-Wilhelm Heinrich, Hermann Sons, Arno Krian. Surgery, Herzzentrum Kaiser Wilhelm Krankenhaus, Duisburg, Germany.

Cardiology 1993;82:343-346. 


\section{Abstract}

Internal mammary artery grafting to the left anterior descending artery gives higher long-term patency and improved survival as compared to venous grafts. Few data exist on the operative mortality and infarction rate in coronary artery bypass surgery when using this type of graft in high-risk groups, such as patients with left main stenosis. In 19 months, we studied 81 consecutive patients with left main stenosis who received a mammary artery graft to the left anterior descending artery as well as vein grafts to other vessels and found no excessive mortality or infarction rate. We suggest that patients with left main stenosis should be treated with an internal mammary artery graft.

\section{Key words}

Internal mammary artery bypass, left main stenosis, coronary artery bypass surgery.

\section{Introduction}

Patients with an internal mammary artery graft to the left anterior descending artery have a more favorable long-term prognosis than those with venous grafts. This concerns the patency rate as well as the rate of survival (1-3). Therefore, this seems to indicate use of the mammary artery bypass as often as possible. However, some doubts exist about internal mammary artery grafting in critical situations such as left main stenosis, unstable angina pectoris or other similar conditions (4-6). Only limited data exist, however, on patients with a mammary artery bypass graft in these high-risk groups. To our knowledge, only one group of 15 patients (7) with left main stenosis has been reported with no negative effects, but no further details concerning this special patient group have been reported. We studied perioperative myocardial infarction rate and mortality in a group of 81 consecutive patients with left main disease who received an internal mammary artery graft to the left anterior descending artery as well as vein grafts to other vessels.

\section{Methods}

The files of all patients receiving a mammary artery graft to the left anterior descending artery during the period of October 1989April 1991 were retrospectively reviewed. In all 81 patients with a 
left main stenosis of $\geq 50 \%$ we analyzed the infarction rate and the in-hospital mortality rate. We tried to relate these data as follows: age, gender, preoperative left ventricular function, severity of left main disease, severity of coronary artery disease, presence of unstable angina pectoris, completeness of revascularization and number of additional bypass grafts. The data were then compared with the literature to see whether or not there was an excessive mortality or infarction rate. Myocardial infarction was diagnosed electrocardiographically (defined as new $Q$-waves) and biochemically (defined as a postoperative CPK-value $\geq$ twice the normal value and having a $\mathrm{CK}-\mathrm{MB} \geq 10 \%$ ).

Data were compared using Student's t-test.

\section{Results}

We found 81 consecutive patients with a left main stenosis of $50-95 \%$, the median being 60\%. There were 66 men, 15 women, ages 35-77 years with a mean of 58.5. Preoperative angiographic left ventricular function was normal in 40 patients (49\%). A wall motion disturbance in 1 segment of the left ventricle was present in $10(12 \%)$, in 2 segments in $12(15 \%)$ and in 3 or more segments in $19(23 \%)$. Left main disease was the only significant coronary pathology in 4 patients (5\%), 1-vessel disease was present in 7 $(9 \%), 2$-vessel disease in $27(33 \%)$ and 3-vessel disease in $43(53 \%)$. Unstable angina pectoris was documented in $11(14 \%)$ patients. Apart from the left internal mammary artery the mean number of venous grafts was 2.3 per patient (range 1-4). In 3 patients, additional measures were taken: thrombendarterectomy in 2 and mitral valve replacement in 1 . Revascularization was considered complete in $68(84 \%)$ and incomplete in $13(16 \%)$.

Complete revascularization was defined as grafting of all main vessels and relevant marginal or diagonal branches showing a stenosis of $\geq 70 \%$.

The hospital mortality rate was $3.7 \%$ ( 3 patients). Two of these patients died because of an intractable rhythm disturbance due to myocardial infarction at the end of the operation. The third death occurred because of a low output syndrome 2 days postoperatively. The 3 patients who died were 48,53 and 59 years of age (mean $53.3 \pm 5.5$ ) while the mean age of the group of survivors was 58.7 \pm 8.1 years (nonsignificant). None of the other evaluated factors (gender, preoperative left ventricular function, severity of left main disease, severity of coronary artery disease, presence of 
unstable angina pectoris, completeness of revascularization and number of additional bypass grafts) tested relevant for the risk of dying (all nonsignificant).

An electrocardiographically diagnosed myocardial infarction was present in 3 (3.8\%) of the surviving 78 patients. Using pure enzymatic criteria an infarction was diagnosed in an additional 5 $(6.4 \%)$ patients, giving a total infarction rate of $10.2 \%$. None of the evaluated factors showed a significant correlation with the occurrence of a myocardial infarction.

\section{Discussion}

Because of the more favorable long-term prognosis of patients receiving an internal mammary artery graft to the left anterior descending artery, it is generally believed that as many patients as possible should receive such a graft. To our knowledge, data have been published on only one series of 15 patients with left main stenosis (7). Patients with a left main stenosis may, therefore, still preferably be treated with a vein graft.

Perioperative mortality in left main disease in recent reports was between $3 \%$ and $5 \%(8-10)$. Atie (10) described in his very recent publication a mortality of $5 \%$. Deaths in his study were registered only in elderly patients with a left main stenosis $>70 \%$ and with multivessel disease. In our patient group no such age relation could be found, the difference in age compared with the survivors was not significant. Left main stenosis was severe in 2, moderate in 1, and all 3 had triple vessel disease as was the case in the patients of Atie et al. Revascularization consisted of 3-4 vein grafts apart from the internal mammary artery graft and was considered complete in all 3 of them. Additional thromboendarterectomy was performed on 1 of these patients.

Perioperative myocardial infarction occurs in about $2.5 \%$ of routine cases electrocardiographically $(9,11)$, but, in up to $15 \%$, enzymatic evidence of some myocardial damage is found without electrocardiographic evidence of a myocardial infarction $(9,11)$. In our surviving 78 patients, an electrocardiographically diagnosed myocardial infarction occurred in $3(3.8 \%)$ patients. One of these 3 patients had an additional thromboendarterectomy and 1 was incompletely revascularized. Their infarcts correlated with both these vessels. The third patient had neither a thromboendarterectomy nor was he incompletely revascularized. Purely enzymatically a myocardial infarction was diagnosed in an additional 5 patients, making a total of $8(10.2 \%)$. This appears to 
be well within normal limits, especially in our high-risk patients. In comparison with the group without a myocardial infarction, none of the evaluated factors showed a significant correlation.

In conclusion, at least in this studied population and in comparison with other data in the literature, it seems that internal mammary artery grafting to the left anterior descending artery in patients with left main disease shows early results which are not inferior to those of venous grafting.

We suggest that patients with left main stenosis should be treated with an internal mammary artery graft. 


\section{Literature}

1 Loop FD, Lytle BW, Cosgrove DM, et al. Influence of the internal mammary-artery graft on 10-year survival and other cardiac events. N Engl J Med 1986;314:1-6.

2 Sergeant P, Lesaffre E, Flameng W, Suy R. Internal mammary artery: methods of use and their effect on survival. Eur J Cardiothorac Surg 1990;4:72-78.

3 Kirklin JW, Naftel DC, Blackstone EH, Pohost GM. Summary of a consensus concerning death and ischemic events after coronary artery bypass grafting. Circulation 1989; 79(suppl I):I-81-91.

4 Flemma RJ, Singh HM, Tector AJ, Lepley D, Frazier BL. Comparative hemodynamic properties of vein and mammary artery in coronary bypass operations. Ann Thorac Surg 1975;20:619-627.

5 Grondin CM, Campeau L, Thornton JC, Engle JC, Cross FS, Schreiber $\mathrm{H}$. Coronary bypass grafting with saphenous vein. Circulation 1989;79(suppl I):I-24-I-29.

6 Lewis MR, Dehmer GJ. Coronary bypass using the internal mammary artery. Am J Cardiol 1985;56:480-482.

7 Kitamura S, Kawachi K, Morita R, et al. Results of internal mammary artery-coronary artery bypass surgery and the characteristics of internal mammary artery grafts. Ipn Circ J 1987;51:1052-1060.

8 Chaitman ER, Fisher LD, Bourassa MG, et al. Effect of coronary bypass surgery on survival patterns in subsets of patients with left main coronary artery disease. Am J Cardiol 1981;48:765777.

9 Kirklin JW, Barrat-Boyes BG. Cardiac surgery. New York: Churchill Livingstone, 1988: 231 pp.

10 Atie J, Brugada P, Brugada J, et al. Clinical presentation and prognosis of left main coronary artery disease in the 1980s. Eur Heart J 1991;12:495-502.

11 ACC/AHA Task Force Report. Guidelines and Indications for Coronary Artery Bypass Graft Surgery. J Am Coll Cardiol 1991;17:543-589. 


\section{UNSTABLE ANGINA PECTORIS AND INTERNAL MAMMARY ARTERY BYPASS GRAFTING}

Ruud Krijne, MD, Reinhard Höltgen, MD.

Department of Cardiology, Herzzentrum Kaiser Wilhelm Krankenhaus, Duisburg, Germany.

Submitted for publication. 


\section{Abstract}

Internal mammary artery to left anterior descending artery graft gives superior long-term patency and survival. Little is known about the operative mortality and perioperative infarction rates using this type of graft in high risk groups, such as unstable angina pectoris. Over a period of $11 / 2$ years we studied 58 consecutive patients who had unstable angina pectoris which was followed by mammary artery grafting during the coronary artery bypass operation. A rather high mortality rate $(6.9 \%)$ and perioperative infarction rate $(18.5 \%)$ were found. We suggest that patients with unstable angina pectoris should not be treated with an internal mammary artery graft.

\section{Key words}

Internal mammary artery, coronary bypass surgery, unstable angina.

\section{Introduction}

The superior results with internal mammary artery grafts to the left anterior descending artery have led to an increased use of this vessel as a bypass conduit in routine coronary artery bypass surgery (1-3). Special risk groups, such as patients with unstable angina, are frequently denied the long-term advantage of an internal mammary artery graft since the use of this vessel is considered to be an extra perioperative risk (4-8). However, only one abstract concerning mortality rate in bypass surgery with mammary artery grafts in this subgroup of patients has been published (9). This abstract showed no mortality in 24 patients.

We reviewed our experience in 58 consecutive patients with unstable angina pectoris who received an internal mammary artery graft.

\section{Methods}

During a period of $11 / 2$ years 58 consecutive patients with unstable angina pectoris received an internal mammary artery graft in our hospital. We used the definition of Rutherford (10): angina pectoris at rest as well as with minimal exertion, angina pectoris of new onset brought on by minimal exertion or crescendo angina. The files of these patients were retrospectively reviewed. Inhospital mortality and perioperative myocardial infarction rates 
were analyzed. A myocardial infarction was diagnosed electrocardiographically (new Q-waves or substantial precordial R-loss) or biochemically. All patients having a postoperative CPK-value $\geq$ twice the normal value and having a CK-MB $\geq 10 \%$ were considered to have suffered from a myocardial infarction. A relation within the following parameters was then sought: age, gender, preoperative left ventricular function, presence of left main disease, severity of coronary artery disease, number of bypass grafts, and completeness of revascularization. We then compared our results with literature data.

\section{Results}

Of the 58 consecutive unstable patients ( 44 men, 14 women, aged $37-85$, with a mean of 60.1$) 56$ received an internal mammary artery graft to the left anterior descending artery, one to the circumflex artery, and one to the first diagonal branch. Preoperative left ventricular function was normal in $21(36 \%)$ patients. A wall motion abnormality in 1 segment was present in $15(26 \%)$, in 2 segments in $8(14 \%)$, and in more than 2 segments in $14(24 \%)$. A left main stenosis of $\geq 50 \%$ was present in 11 (19\%) patients, the mean degree of stenosis being $69.5 \%$. Three vessel disease was present in $34(58.6 \%)$ patients, two vessel disease in 16 (27.6\%), and one vessel disease in 7 (12.1\%). Only a main stem stenosis was present in $1(1.7 \%)$. A part from the internal mammary artery graft the mean number of grafts was 1.9 (range 0-4). Complete revascularization was reached in as many as 50 patients $(86 \%)$, while incomplete revascularization was possible in only $8(14 \%)$.

Of the 58 patients $4(6.9 \%)$ died in hospital; 1 in tabula, 3 in the early postoperative period and all of cardiac causes.

According to electrocardiographic criteria myocardial infarction occurred in $5(9.3 \%)$ of the 54 surviving patients and 4 of these 5 were anterior wall infarctions. A pure enzymatically diagnosed myocardial infarction was present in an additional 5 patients making a total infarction rate of $18.5 \%$.

\section{Discussion}

According to a large collected review (11) mortality in coronary artery bypass surgery in unstable angina pectoris ranges between $1.2 \%$ and $8.5 \%$. Infarction rate ranges between $3.8 \%$ and $17 \%$. No mention of internal mammary artery grafting is made in these reviewed reports, however. Patients with unstable angina pectoris 
are frequently denied the long-term advantage of an internal mammary artery graft since the extra preparation time may be detrinnental to the patient $(5,6)$ and flow adaptation of an internal mammary artery graft does not occur immediately.

Mortality rate in our patient group was $6.9 \%$ which is in the upper range of the above mentioned review. The $18.5 \%$ myocardial infarction rate exceeds these limits. Four of the 5 electrocardiographically diagnosed infarctions were in the anterior wall and within that part of the heart supplied by the internal mammary artery graft. This suggests that rapidity of flow adaptation is indeed a problem in unstable patients. In comparison with the group without a myocardial infarction none of the other evaluated factors showed a significant correlation.

Ours was only a retrospective analysis and our comparison was with literature data only; moreover, we studied a disease entity which is non-uniform. Despite these restrictions the conclusion seems justified that mammary artery surgery in unstable angina pectoris is indeed an extra risk factor. This risk factor is especially true for the development of an anterior wall myocardial infarction and, therefore, internal mammary artery grafting should not be performed on patients with unstable angina pectoris. 


\section{Literature}

1 Loop FD, Lytle BW, Cosgrove DM, et al. Influence of the internal mammary-artery graft on 10-year survival and other cardiac events. N. Engl. J. Med. 1986;314:1-6.

2 Sergeant $P$, Lesaffre E, Flameng W, Suy R. Internal mammary artery: methods of use and their effect on survival. Eur. J. Cardiothorac. Surg. 1990;4:72-78.

3 Kirklin JW, Naftel DC, Blackstone EH, Pohost GM. Summary of a consensus concerning death and ischemic events after coronary bypass grafting. Circulation 1989;79(suppl I):I-81-I91.

4 Flemma RJ, Singh HM, Tector AJ, Lepley D, Frazier BL. Comparative hemodynamic properties of vein and mammary artery in coronary bypass operations. Ann. Thorac. Surg. 1975;20:619-627.

5 Geha AS, Baue AE. Early and late results of coronary revascularization with saphenous vein and internal mammary artery grafts. Am. J. Surg. 1979;137:456-463.

6 Loop FD, Irarrazaval MJ, Bredée JJ, Siegel W, Sheldon WC. Internal mammary artery graft for ischemic heart disease. Am. J. Cardiol. 1977;39:516-522.

7 Grondin CM, Campeau L, Thornton JC, Engle JC, Cross FS, Schreiber $\mathrm{H}$. Coronary bypass grafting with saphenous vein. Circulation 1989;79(suppl I)I-24-I-29

8 Lewis MR, Dehmer GJ. Coronary bypass using the internal mammary artery. Am. J. Cardiol. 1985;56:480-482.

9 Geha AS, McCormick JR, Baue AE. Use of internal mammary artery grafts in the treatment of preinfarction angina. Circulation 1974;50(suppl III)III-174 (Abstract)

10 Rutherford JD, Braunwald E, Cohn PF. Chronic ischemic heart disease. In: Braunwald E, ed., Heart Disease. Philadelphia: W.B. Saunders Company, 1988:1353.

11 Kaiser GC, Schaff HV, Killip T. Myocardial revascularization for unstable angina pectoris. Circulation 1989;79(suppl I):I-60I-67. 



\section{COMBINED \\ TWO-DIMENSIONAL AND \\ DOPPLER SONOGRAPHIC \\ EXAMINATION OF \\ INTERNAL MAMMARY \\ ARTERY GRAFTS FROM \\ THE SUPRACLAVICULAR \\ FOSSA}

Ruud Krijne, Ralf M. Lyttwin, Reinhard Höltgen,

Karl-Wilhelm Heinrich, Roger Marx, Hermann Sons.

Departments of Cardiology and Thoracic and Cardiovascular Surgery, Herzzentrum Kaiser Wilhelm Krankenhaus, Duisburg, Germany.

Int. J. Cardiol 1992;37:61-64. 


\section{Abstract}

The noninvasive examination of internal mammary artery grafts is gaining importance with the increasing use of this vessel in the surgical treatment of coronary atherosclerosis of the left anterior descending artery. We studied 36 patients ( 37 internal mammary artery grafts) with combined two-dimensional and pulsed Doppler echography from the supraclavicular fossa. Adequate visualization and Doppler signals were obtained in $95 \%$ of arterial grafts. Twenty-four grafts leading to an area without evidence of old myocardial infarction or ischemia and 10 grafts leading to an area of old myocardial infarction but without evidence of ischemia on exercise showed a significant decrease of the peak systolic velocity and of the peak systolic velocity / peak diastolic velocity ratio as compared to the controls, which consisted of the contralateral internal mammary arteries in situ. One patient with a distally subtotally occluded mammary artery graft had a flow pattern different from the other bypassed mammary arteries. It seems that combined two-dimensional and pulsed Doppler sonography is a useful method to evaluate the functional status of internal mammary artery grafts.

\section{Key words}

Internal mammary artery, Coronary artery bypass surgery, Doppler echography.

\section{Introduction}

Excellent long-term patency and improved survival (1-3) has led to the frequent use of the internal mammary artery as the graft of choice for revascularization of the heart, especially for the left anterior descending artery. Therefore, noninvasive functional evaluation of this bypass is gaining importance. One approach is the transthoracic echographic examination of bypass patency and flow measurement (4). Limitations of this method, however, are the estimate of the Doppler incident angle for absolute measurement of graft flow (5) and the limited number of patients in which adequate signals can be obtained.

We studied a group of postoperative patients by measuring graft flow by combined two-dimensional and pulsed Doppler sonography from the supraclavicular fossa to evaluate whether acceptable results regarding echo signals, including velocity and flow measurements could be obtained. 


\section{Materials and Methods}

In 36 consecutive patients ( 33 men, 3 women, age 34 to 77 years, mean 60,3 years) semiselective angiography of both internal mammary arteries was performed at the end of coronary arteriography to exclude atherosclerotic changes. A diameter stenosis of 75$100 \%$ was present in 35 patients in the left anterior descending artery and in 2 patients in the right coronary artery. Four to 30 months (mean 15,3) after coronary bypass surgery, in which the left internal mammary artery was used as a graft to the left anterior descending artery in 35 patients and the right internal mammary artery as a graft to the right coronary artery in 2 patients (giving a total of 37 grafts), these internal mammary artery conduits were visualized by combined two-dimensional and Doppler echography from the supraclavicular fossa using a Vingmed CFM 750 with a $7.5 \mathrm{MHz}$ annular array probe for the two-dimensional image and a $6 \mathrm{MHz}$ frequency for the pulsed Doppler signal with sample volume location. Graft diameter at its origin, maximal systolic and diastolic graft flow velocity were measured. Angle correction was applied for the velocity measurements. The same measurements were taken from the corresponding non-bypassed mammary arteries. In all patients evidence of myocardial ischemia or infarction was sought by rest and exercise electrocardiography and standard echocardiography. To see whether blood flow was different in grafts leading to normal myocardium, infarcted areas or ischemic areas we divided our patients in these three groups.

Postoperative angiography of the mammary artery graft was performed in 4 patients because of recurrent angina and postoperative ventricular fibrillation, 3 arteries were patent, 1 was subtotally occluded.

Statistical analysis was done with Student's t-test

\section{Results}

Thirty-five of 37 (95\%) of the arterial grafts could be visualized, 33 left- and 2 right-sided. Two grafts could not be visualized, both in patients with obstructive lung disease. The diameter of the grafts we found was $1.8-3.9 \mathrm{~mm}$ (mean 2.8 ) compared to the nearly equal value of $1.9-4.0 \mathrm{~mm}$ (mean 2.8) in the non-bypassed internal mammary arteries. The Doppler incident angle was 22-80 degrees (mean 65), the absolute flow values were computed between 30 and 120 (mean 90) $\mathrm{ml} / \mathrm{min}$. 


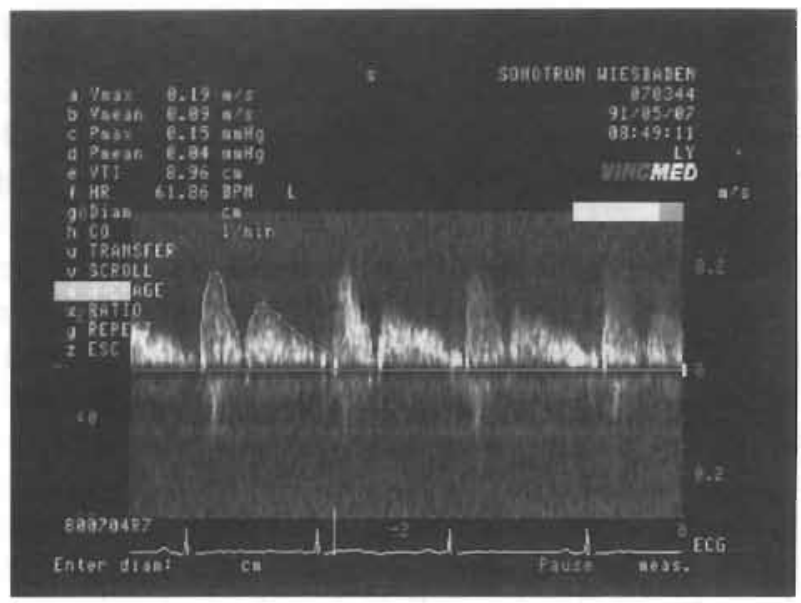

Figure 1. Internal mammary artery graft, typical flow pattern as seen from th' supraclavicular fossa.

In 22 patients with a left-sided bypass there were no old myocardial infarctions or indications of ischemia on exercise. In their grafts the peak systolic velocity was $0.54 \pm 0.39 \mathrm{~m} / \mathrm{s}$ (mean \pm 1 standard deviation), the peak diastolic velocity was $0.29 \pm 0.24$ $\mathrm{m} / \mathrm{s}$. The corresponding values in the mammary arteries left in situ were $1.24 \pm 0.87$ and $0.20 \pm 0.16 \mathrm{~m} / \mathrm{s}$. The difference in peak systolic velocity was significant ( $p<0.05)$, the difference in diastolic velocity was not. The peak systolic velocity / peak diastolic velocity ratio in the bypass was $1.94 \pm 0.5$ versus $7.66 \pm 7.3$ ( $p<$ $0.05)$ in the internal mammary artery in situ. Typical flow patterns are shown in figures 1 and 2 .

There were 10 patients with signs of an old anterior wall myocardial infarction on electrocardiogram or echocardiography, but without signs of ischemia on exercise. Peak systolic velocity was $0.63 \pm 0.37 \mathrm{~m} / \mathrm{s}$ versus $1.37 \pm 0.54(\mathrm{p}<0.05)$, peak diastolic velocity was $0.33 \pm 0.22 \mathrm{~m} / \mathrm{s}$ versus $0.28 \pm 0.25$ (difference not significant). Peak systolic velocity / peak diastolic velocity was $2.01 \pm 0.61$ versus $19.2 \pm 42(\mathrm{p}<0.05)$.

The velocity values of the patients with and without old myocardial infarction were not significantly different.

There was 1 patient with signs of ischemia, whose internal mammary artery graft was shown on angiography to be subtotally occluded at the peripheral anastomosis. His peak systolic velocity was $1.86 \mathrm{~m} / \mathrm{s}$, his peak diastolic velocity $0.03 \mathrm{~m} / \mathrm{s}$, so the values 


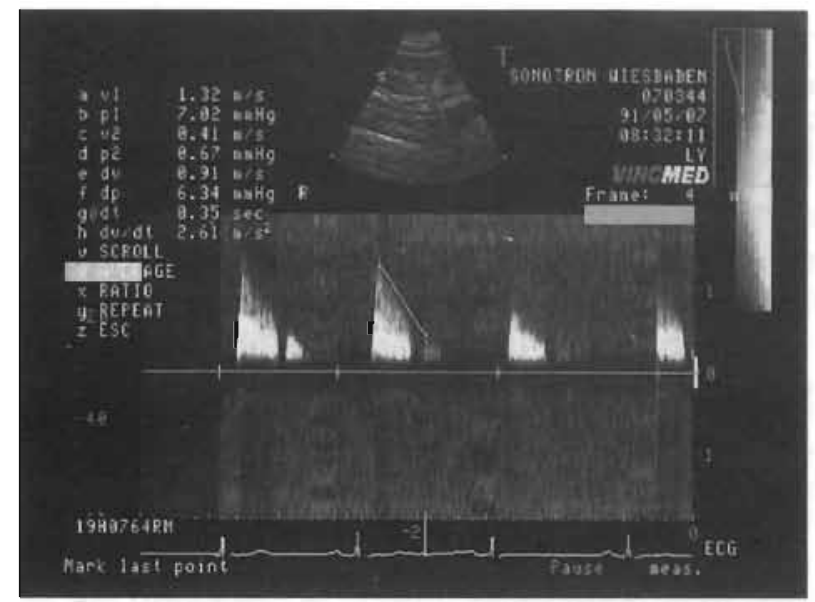

Figure 2. Mammary artery in situ, typical flow pattern as seen from the supraclavicular fossa (scale different from Fig. 1.).

were clearly different from the other grafted vessels. The 2 patients with a right-sided internal mammary artery graft had flow patterns like the left-sided grafts.

\section{Discussion}

Increasing use of the internal mammary artery as a bypass graft makes non-invasive evaluation of its function more important. Sons et al. found that postoperative duplex scanning of the internal mammary artery to establish its patency correlated well with angiographic findings (6). On transthoracic examination Fusejima (4) could discern 11 of $14(79 \%)$ internal mammary artery grafts and found flow patterns similar to those in the recipient coronary artery. He found a biphasic flow pattern with higher diastolic than systolic flow. This is contradicted by both our results and those of Spierenburg (7) which demonstrate the opposite: higher peak systolic than diastolic velocities. This could be due to sampling volume location: in Spierenburg's and our population very proximal in the mammary artery graft, in the study of Fusejima rather distal. In that case the proximal flow pattern could be the transition of typical subclavian to typical coronary flow. The difference in sample position could also explain why only a non-significant increase in absolute peak diastolic flow velocity was found as compared to the results of Fusejima and Spierenburg. 
In our study the population of patients without evidence of old myocardial infarction or ischemia on exercise showed a significant decrease in peak systolic velocity and in peak systolic / peak diastolic velocity ratio as compared to the corresponding internal mammary arteries in situ. The same flow pattern was found in the group of patients with evidence of an old myocardial infarction but without ischemia on exercise, so at least in our patient population it seems that graft flow characteristics are not influenced by old myocardial damage. The only patient with ischemia on exercise was found to have a nearly occluded mammary artery graft and his flow pattern was different from the other bypassed mammary arteries.

Good anatomic orientation is crucial in measuring flow velocities in internal mammary artery grafts. In our study the central landmark was the subclavian artery and its side branches the vertebral artery and the thyreocervical truncus. This orientation enabled the conclusion that the Doppler signal belonged to the mammary artery.

As our Doppler incident angle was large (mean 65 degrees), we refrained from discussing absolute flow values.

In conclusion, we think that combined two-dimensional and pulsed Doppler sonography of internal mammary artery grafts from the supraclavicular fossa is in most cases possible and gives useful information on the flow pattern in the graft and thus to its function. Although adequate signals could be obtained from the supraclavicular fossa in $95 \%$ of patients versus $79 \%$ by transthoracic echography, Doppler angles were in the same range as in the study of Fusejima, so absolute measurement of graft flow remains difficult. Further partly invasive studies, however, are necessary to confirm our findings. 


\section{Literature}

1 Loop FD, Lytle BW, Cosgrove DM, et al. Influence of the internal mammary-artery graft on 10-year survival and other cardiac events. N Engl J Med 1986;314:1-6.

2 Sergeant $P$, Lesaffre E, Flameng $W$, Suy R. Internal mammary artery: methods of use and their effect on survival. Eur J Cardiothorac Surg 1990;4:72-78.

3 Kirklin JW, Naftel DC, Blackstone EH, Pohost GM. Summary of a consensus concerning death and ischemic events after coronary artery bypass grafting. Circulation 1989; 79(suppl I): $1-81-91$.

4 Fusejima K, Takahara Y, Sudo Y, Murayama H, Masuda Y, Inagaki $Y$. Comparison of coronary hemodynamics in patients with internal mammary artery and saphenous vein coronary artery bypass grafts: a noninvasive approach using combined two-dimensional and Doppler echocardiography. JACC 1990;15:131-139.

5 Lighty GW. Duplex Doppler evaluation of coronary artery and bypass graft flow: a practical clinical tool? JACC 1991;15:140142.

6 Sons H, Becker T, Marx R, Lösse B, Schulte HD, Bircks W. Postoperative ultrasonic Duplex scanning of the internal mammary artery. Eur Heart J 1989:10 (suppl):304 (abstract).

7 Spierenburg HAM, Jaarsma W, Visser CA, Akerstaff RCA, Vermeulen FEE, Ascoop CAPL. Noninvasive evaluation of the internal mammary artery by ultrasonic Duplex scanning. Eur Heart J 1989:10 (suppl):358 (abstract). 



\section{DOPPLER SONOGRAPHIC EXAMINATION OF THE INTERNAL MAMMARY ARTERY GRAFT: COMPARISON OF SUPRACLAVICULAR AND HIGH INTERCOSTAL SIGNALS}

Ruud Krijne, Ralf M. Lyttwin, Reinhard Höltgen, Karl-Wilhelm Heinrich.

Department of Cardiology, Herzzentrum Kaiser Wilhelm Krankenhaus, Duishurg, FRG.

Cardiology 1993;82:48-50. 


\section{Abstract:}

In a group of 22 patients, Doppler signals from the proximal part of the internal mammary artery graft were studied from the supraclavicular fossa as well as from the high intercostal spaces. An adequate signal was found more often from the supraclavicular position. Both positions gave a peak systolic velocity higher than peak diastolic velocity. Transition of the flow to the typical coronary flow pattern with higher peak diastolic velocity seems to occur in lower parts of the graft.

\section{Key words}

Doppler sonography, mammary artery graft, coronary artery bypass surgery.

\section{Introduction}

Doppler ultrasonography of mammary artery graft flow represents an investigational method. Its applicability is limited by the rate of vessel detection and the influence of the Doppler incident angle on the measurement of absolute graft flow (1). Another aspect of the internal mammary artery graft is the shift of the highest flow velocity from the systole in the subclavian artery to the diastole in the coronary artery (1-4). This change in the flow velocity pattern probably occurs in the mammary artery graft. To evaluate this phenomenon, we compared the Doppler signals from two different anatomic sites: supraclavicular and high intercostal spaces.

\section{Methods}

We performed a combined two-dimensional and Doppler sonographic study of the proximal part of the internal mammary artery graft in 22 patients, 6-26 (mean 15) months after coronary artery bypass surgery. A Vingmed CFM 750 echo machine with a $7.5 \mathrm{MHz}$ annular array probe for the two-dimensional image and a $6 \mathrm{MHz}$ frequency for the pulsed Doppler signal with sample volume location were used. Patients were investigated from the supraclavicular fossa and from the highest possible intercostal space. Special care was taken to ensure anatomic validation of the Doppler signal. Angle correction was applied for the velocity measurements. Angle of the Doppler signal, maximal systolic and 
diastolic velocities and duration of systolic and diastolic flow signals were registered. The data were analyzed by Student's t-test.

\section{Results}

In $21(95 \%)$ of patients an adequate image and flow signal were obtained from the supraclavicular fossa, compared to 16 patients $(73 \%)$ in whom an adequate investigation could be performed from the first ( 3 patients), second (10 patients) and third ( 3 patients) intercostal space. In $1(5 \%)$ patient no adequate signal was obtained from both positions. Heart rate during the examination was $47-83$ (mean 67 ) beats/min. The angle of the Doppler signal was 44-80 degrees (mean 69) from the supraclavicular fossa and 50-80 (mean 72) degrees from the intercostal space (difference not significant). Maximal systolic velocity was $0.26-2.08$ (mean 1.12 ) $\mathrm{m} / \mathrm{s}$ from the supraclavicular fossa and 0.35-1.94 (mean 1.01) $\mathrm{m} / \mathrm{s}$ from the intercostal spaces (difference not significant). Maximal diastolic velocity was $0.16-1.29$ (mean 0.54 ) $\mathrm{m} / \mathrm{s}$ from supraclavicular and $0.10-0.82$ (mean 0.40 ) $\mathrm{m} / \mathrm{s}$ from intercostal (difference not significant). Duration of the systolic and diastolic flow signals were $0.24-0.43$ (mean 0.31) $\mathrm{s}$ and 0.41-0.82 (mean 0.55) $\mathrm{s}$, from the supraclavicular fossa, as compared to 0.28-0.40 (mean 0.32 ) $\mathrm{s}$ and $0.36-1.01$ (mean 0.56) $\mathrm{s}$ from the intercostal spaces (difference not significant)

\section{Discussion}

Since 1972 the applicability of noninvasive investigation of coronary artery bypass flow has been under study $(5,6)$ and the detection rate of the graft as well as the absolute flow measurement have been problematic. Fusejima et al. (1) recently reported an investigation in which, in 11 of 14 patients with internal mammary artery graft, flow signals could be obtained and described from a precordial transducer position. In their investigation they found higher diastolic than systolic flow velocities. Our own study of the flow pattern in the proximal part of the graft from the supraclavicular fossa in 36 patients and the study of De Bono et al. is in contrast to this $(2,4)$. We now have studied a group of patients from two sites: supraclavicular and high intercostal spaces. The detection rate was higher from the supraclavicular fossa than from the high intercostal position. Doppler angle, peak systolic and peak diastolic velocities and durations of systolic and dias- 
tolic flows were not significantly different in both sites. In fact, signals from both positions were rather comparable. In both positions systolic flow velocity was higher than diastolic flow velocity. Combining our measurements in the proximal part of the internal mammary artery graft and the results of Fusejima (1) we conclude that the transition in the flow pattern probably occurs in the middle or lower part of the grafted vessel. 


\section{Literature}

1 Fusejima K, Takahara Y, Sudo Y, Murayama H, Masuda Y, Inagaki $Y$. Comparison of coronary hemodynamics in patients with internal mammary artery and saphenous vein coronary artery bypass grafts: a noninvasive approach using combined two-dimensional and Doppler echocardiography. J Am Coll Cardiol 1990;15:131-139.

2 Krijne R, Lyttwin RM, Höltgen R, Heinrich K-W, Marx R, Sons $\mathrm{H}$. Combined two-dimensional and Doppler sonographic examination of internal mammary artery grafts from the supraclavicular fossa. Int J Cardiol 1992;37:61-64.

3 Kyo S, Matsumura M, Yokote Y, Takaomoto S, Omoto R. Evaluation of patency of internal mammary artry grafts: a comparison of two-dimensional Doppler echocardiography with coronary angiography. J Cardiol 1990;20(3):607-616.

4 de Bono DP, Samani NJ, Spyt TJ, Hartshorne T, Trush HJ, Evans DH. Transcutaneous ultrasound measurement of blood flow in internal mammary to coronary artery grafts. Lancet 1992;339:378-381.

5 Gould KL, Mozersky CJ, Hokanson DE, e.a. A noninvasive technic for determining patency of saphenous vein coronary bypass grafts. Circulation 1972;46:595-600.

6 Diebold B, Theroux P, Bourassa MG, Peronneau P, Guermonprez J. Noninvasive assessment of aortocoronary bypass graft patency using pulsed Doppler echocardiography. Am J Cardiol 1979;43:10-13. 



\section{DOPPLER SONOGRAPHIC}

EXAMINATION OF THE INTERNAL MAMMARY ARTERY GRAFT: INFLUENCE OF EXERCISE

Ruud Krijne, Ralf M. Lyttwin, Reinhard Höltgen and Karl-Wilhelm Heinrich.

Department of Cardiology, Herzzentrum Kaiser Wilhelm Krankenhaus, Duisburg, Germany.

Int J Cardiol 1993;39:163-165 


\section{Abstract}

With the frequent use and excellent longevity of the internal mammary artery graft, knowledge about the behaviour of this graft under different conditions is becoming relevant. We studied 20 patients with combined two-dimensional and pulsed Doppler sonography before and after exercise testing and established values for peak velocities and flow duration. During exercise flow duration shortened in systole and diastole in the same order of magnitude, peak diastolic velocity especially increased during exercise.

\section{Introduction}

Excellent longevity and survival with the use of the internal mammary artery as a graft to the left anterior descending artery (1-3) makes knowledge about the behaviour of this vessel under different conditions relevant. One non-invasive approach is evaluation of graft function by Doppler sonography (4-7). We studied a group of postoperative patients by measuring graft flow signal before and after exercise.

\section{Methods}

In 20 consecutive patients ( 16 men, 4 women, age $41-70$ years, mean 59.3) combined two-dimensional and Doppler sonographic examination of the internal mammary artery graft was performed from the supraclavicular fossa. In all patients the graft was on the left anterior descending artery. The study was done 6-26 months (mean 14) after operation. A Vingmed CFM 750 echo machine was used with a $7.5 \mathrm{MHz}$ annular array probe for the two-dimensional image and a $6 \mathrm{MHz}$ frequency for the pulsed Doppler signal with sample volume location (7). Angle correction was applied for the velocity measurements. The patients were examined before and after symptom limited bicycle ergometry. Heart rate during examination before and after exercise as well as use of $\beta$-blocking medication were registered. The following measurements were taken by Doppler sonography: peak systolic velocity, peak diastolic velocity, duration of systolic and diastolic flow and velocity time integral. Peak diastolic / peak systolic velocity and systolic / diastolic flow were computed. Values were compared before and after exercise, in patients with and without $\beta$-blocker therapy.

Statistical analysis was done with Student's t-test. 


\begin{tabular}{|c|c|c|c|c|}
\hline & \multicolumn{2}{|c|}{ no $\beta$-blocker } & \multicolumn{2}{|l|}{$\beta$-blocker } \\
\hline & rest & exercise & rest & exercise \\
\hline heart rate (beats / min) & $72 \pm 9$ & $91 \pm 18$ & $62 \pm 7$ & $75 \pm 8$ \\
\hline peak systolic velocity (m /s) & $0.99 \pm 0.56$ & $1.21 \pm 0.46$ & $1.90 \pm 0.40$ & $1.43 \pm 0.78$ \\
\hline $\begin{array}{l}\text { peak diastolic velocity }(\mathrm{m} / \mathrm{s}) \\
\text { peak systolic / diastolic }\end{array}$ & $0.45 \pm 0.22$ & $0.76 \pm 0.34$ & $0.61 \pm 0.30$ & $0.72 \pm 0.37$ \\
\hline velocity ratio & $2.2 \pm 0.5$ & $1.7 \pm 0.5$ & $2.2 \pm 0.7$ & $2.2 \pm 0.9$ \\
\hline duration systolic flow (s) & $0.31 \pm 0.03$ & $0.25 \pm 0.05$ & $0.31 \pm 0.03$ & $0.29 \pm 0.05$ \\
\hline duration diastolic flow (s) & $0.53 \pm 0.13$ & $0.40 \pm 0.10$ & $0.62 \pm 0.10$ & $0.51 \pm 0.09$ \\
\hline velocity time integral & $36 \pm 20$ & $37 \pm 13$ & $51 \pm 16$ & $47 \pm 20$ \\
\hline
\end{tabular}

\section{Results}

There were 10 patients receiving $\beta$-blocking therapy, 10 patients were not. In 19 patients no evidence of ischemia was found by exercise testing, in one patient angina pectoris occurred, accompanied by a significant ST-segment depression in lead V6.

Doppler incident angle was 44 - 80 degrees, mean 69 degreus.

The data on heart rate, flow velocity and duration, and velocity time integral are listed in the table. In patients receiving no $\beta$ blocking medication heart rate in rest and after exercise was significantly different $(p<0.05)$. After exercise peak systolic velocity increased non-significantly, peak diastolic velocity increased significantly, peak systolic / peak diastolic velocity ratio decreased slightly. Flow duration shortened significantly $(p<0.05)$ in systole and diastole after exercise, both in the same order of magnitude (systolic to $81 \%$ of the value in rest, diastolic to $75 \%$ of the value in rest). The velocity time integral increased after exercise, the difference as compared to before exercise was non-significant.

In patients on $\beta$-blocker therapy (metroprolol 50-150 mg, mean $100 \mathrm{mg}$ ) heart rate in rest was significantly lower $(\mathrm{p}<0.05)$ as compared to the non- $\beta$-blocker group. Flow at rest did not differ from patients without $\beta$-blocker therapy, either in peak velocities, or in duration of the systolic and diastolic flow signal.

After exercise heart rate in the $\beta$-blocker group was significantly $(p<0.05)$ higher than in rest. Peak systolic velocity increased as 
did peak diastolic velocity, but the difference as compared to the rest values were not significant. The shortening in diastolic flow duration was significantly more than in rest $(\mathrm{p}<0.05)$ and significantly more than in the non $\beta$-blocker group $(p<0.05)$. Systolic / diastolic flow duration ratio did also change relevantly $(\mathrm{p}<$ 0.05 ). The velocity time integral was not significantly different from the value before exercise.

\section{Discussion}

The internal mammary artery has become the standard bypass vessel for grafting to the left anterior descending artery because of its longevity and increased long-term survival. Therefore knowledge of the behaviour of this vessel under different circumstances is a relevant issue, apart from the fact that echography of this vessel opens possibilities for direct non-invasive study of coronary artery flow. Little data exist on echographic flow characteristics and no data at all concerning influence of exercise or $\beta$-blockade. A very practical problem in our study was the time interval between the end of the exercise test and the moment of obtaining a reliable Doppler signal.

Bearing this in mind we present the above mentioned data showing that during exercise especially peak diastolic velocity increases, flow duration shortens in systole and diastole in the same order of magnitude, suggesting that velocity increase could be the main mechanism of flow increase. $\beta$-Blockade gives no relevant change in flow signal as compared to patients not on $\beta$-blocker therapy in rest. 


\section{Literature}

1 Loop FD, Lytle BW, Cosgrove DM, et al. Influence of the internal mammary-artery graft on 10-year survival and other cardiac events. N. Engl. J. Med. 1986;314:1-6.

2 Sergeant $P$, Lesaffre $E$, Flameng $W$, Suy R. Internal mammary artery: methods of use and their effect on survival. Eur. J. Cardiothorac. Surg. 1990;4:72-78.

3 Kirklin JW, Naftel DC, Blackstone EH, Pohost GM. Summary of a consensus concerning death and ischemic events after coronary artery bypass grafting. Circulation 1989; 79(suppl I):I-81-91.

4 Fusejima K, Takahara Y, Sudo Y, Murayama H, Masuda Y, Inagaki $Y$. Comparison of coronary hemodynamics in patients with internal mammary artery and saphenous vein coronary artery bypass grafts: a noninvasive approach using combined two-dimensional and Doppler echocardiography. JACC 1990;15:131-139.

5 Lighty GW. Duplex Doppler evaluation of coronary artery and bypass graft flow: a practical clinical tool? JACC 1991;15:140142.

6 Bono DP de, Samani NJ, Spyt TJ, Hartshorne T, Trush HJ, Evans DH. Transcutaneous ultrasound measurement of blood flow in internal mammary to coronary artery grafts. Lancet 1992;339:378-381.

7 Krijne R, Lyttwin RM, Höltgen R, Heinrich K-W, Marx R, Sons $H$. Combined two-dimensional and Doppler sonographic examination of internal mammary artery grafts from the supraclavicular fossa. Int. J. Cardiol. 1992;37:61-64. 



\section{CONCLUSIONS AND SUMMARY}

The treatment of coronary artery disease often consists of bypass surgery and a preferred bypass vessel is the internal mammary artery, because of the excellent results of this bypass vessel. After a review of the development of coronary artery bypass surgery especially in respect to the internal mammary artery graft in chapter 2, several aspects of the internal mammary artery graft are discussed. The assessment of atherosclerotic disease of the internal mammary artery has systematically been performed in only a few studies, most of them including also patients without coronary artery disease. Chapter 3 shows that in a group of patients with significant coronary artery disease atherosclerotic changes of the internal mammary artery are relatively rare as seen by angiographic examination. Routine preoperative angiography therefore seems unnecessary.

A comparison of arteriographic findings of the internal mammary artery and intraoperatively assessed suitability of the vessel has not been performed so far. In chapter 4 we evaluate the preoperative angiographic findings and the effective use of the internal mammary artery as decided by the cardiac surgeon. There are more grafts which are rejected than those with atherosclerotic changes. Possible reasons for this discrepancy are spasm or intraoperative vessel damage.

Use of the internal mammary artery graft in high-risk situations is a matter of debate. However the outcome in these patient groups has not been systematically evaluated so far. We compare the outcome of two high-risk groups after grafting with the internal mammary artery namely left main coronary artery stenosis and unstable angina pectoris. Chapter 5 describes the favourable results of internal mammary artery grafting in the group of patients with left main stenosis. Contrary to this group, rather 
unfavourable results in patients with unstable angina pectoris are reported in chapter 6. Apparently some high-risk patients may profit from internal mammary artery grafting while others do not. Further studies in this field are necessary to establish the best therapeutic approach for each individual patient. This could lead to a more differentiated use of the internal mammary artery as a bypass graft.

Evaluation of graft function in postoperative patients is important if symptoms of coronary artery disease reoccur. Up until now angiography is the only method employed. However the internal mammary artery bypass graft is difficult to visualize selectively by this technique. Besides, a non-invasive test would be preferable. Doppler evaluation of the mammary artery graft is an investigational method. Chapter 7 shows that it is very well possible to obtain adequate Doppler signals from the native internal mammary artery as well as from the mammary artery graft with the Doppler probe positioned in the supraclavicular fossa. With this Doppler signal we gain an impression of the functional status of the graft.

Searching for the optimal transducer position we compare the supraclavicular fossa with a high intercostal echo-transducer position, as described in chapter 8 . The latter position, however, results in adequate signals in fewer patients.

Examination after exercise (chapter 9) shows changes in the Doppler flow pattern as compared to values in rest. Especially peak diastolic velocity increases. As the time interval between the end of exercise and the moment of obtaining an adequate Doppler signal is relatively long the results of this study are difficult to interpret.

In conclusion it seems that non-invasive Doppler investigation of internal mammary artery graft flow is a promising technique. Its value as compared to standard catheter techniques has to be established in further studies. 


\section{SCHLUSSFOLGERUNGEN UND \\ ZUSAMMENFASSUNG}

Die Behandlung der koronaren Herzkrankheit besteht häufig aus einer chirurgischen Überbrückungstherapie. Die Arteria mammaria interna ist das bevorzugte Gefäss für Überbrückungen, wegen hervorragender Langzeitergebnisse. Nach einem Überblick über die Entwicklung der koronaren Herzchirurgie, vor allem in Bezug auf die Arteria mammaria als Überbrückungsgefäss in Kapitel 2 werden unterschiedliche Aspekte dieses Gefässes diskutiert. Die Untersuchung atherosklerotischer Erkrankungen der Arteria mammaria interna ist nur in wenigen Studien systematisch erfolgt, wobei in den meisten Studien auch Patienten ohne koronaren Herzerkrankungen aufgenommen waren. Kapitel 3 zeigt mittels Angiographie dass atherosklerotische Veränderungen der Arteria mammaria interna in einer Patientengruppe mit einer relevanten koronaren Herzerkrankung relativ selten sind. Routinemässige präoperative Angiographie erscheint deswegen unnötig.

Ein Vergleich der arteriographischen Befunde der Arteria mammaria interna mit der intraoperativen Brauchbarkeit des Gefässes ist bis jetzt nicht durchgeführt worden. In Kapitel 4 werden die präoperativen angiographischen Untersuchungen und die effektive Anwendung der Arteria mammaria interna in der Herzchirurgie evaluiert. Es stellt sich heraus, dass intraoperativ auch Gefässe als bypassuntauglich abgelehnt werden, die nicht atherosklerotisch verändert sind. Mögliche Gründe für diese Diskrepanz sind Spasmen oder intraoperative Gefässverletzungen.

Die Anwendung der Arteria mammaria interna in hoch-Risiko Patienten ist diskutabel. Das Ergebnis in diesen Patientengruppen ist bis jetzt nicht systematisch untersucht worden. Wir vergleichen die Ergebnisse in zwei hoch-Risiko Gruppen bei Über- 
brückungsoperationen mit Hilfe der Arteria mammaria interna, nämlich Hauptstammstenose und instabile Angina pectoris. Kapitel 5 beschreibt die günstigen Resultate der Überbrückungsoperationen mit Hilfe der Arteria mammaria bei Patienten mit einer Hauptstammstenose. Im Gegensatz dazu sind die Ergebnisse bei der anderen hoch-Risiko Kategorie, Patienten mit instabiler Angina pectoris (Kapitel 6) deutlich schlechter. Offensichtlich profitieren nicht alle hoch-Risiko Patienten von einer Operation mit Hilfe der Arteria mammaria interna. Weitere Untersuchungen in diesem Bereich sind erforderlich um die beste Behandlungsmethode für jeden einzelnen Patienten zu erforschen. Dies könnte zu einem mehr differenzierten Gebrauch der Arteria mammaria interna als Überbrückungsgefäss führen.

Postoperative Untersuchung der Funktion des Überbrückungsgefässes ist wesentlich wenn Symptome der koronaren Herzerkrankung erneut auftreten. Bis zu diesem Augenblick ist Angiographie die einzige Methode der Darstellung. Die Arteria mammaria interna ist aber relativ schwer selektiv mit dieser Technik darzustellen. Ausserdem würde eine nicht-invasive Untersuchungsmethode den Vorzug verdienen. Die Doppler Untersuchung der Arteria mammaria ist eine Methode die noch in der Entwicklung ist. Kapitel 7 zeigt, dass es sehr wohl möglich ist ausreichende Doppler Signale von der nativen Arteria mammaria interna, als auch von dem als Überbrückung angewandten Gefäss zu bekommen mit dem Dopplerschallkopf im supraklavikularen Raum. Mit diesem Dopplersignal erhalten wir einen Eindruck über die Funktion des Überbrückungsgefässes.

Auf der Suche nach der optimalen Schallkopfposition vergleichen wir den supraklavikularen Raum mit einer hoch-interkostalen Position, wie in Kapitel 8 beschrieben. Letztere Position erzielt aber bei wenigeren Patienten ein ausreichendes Signal.

Untersuchungen nach Belastung (Kapitel 9) zeigen Veränderungen im Dopplerflussmuster im Vergleich zu den Werten im Ruhezustand. Da aber das Zeitintervall zwischen Belastungsende und dem Augenblick wo ein ausreichendes Dopplersignal gefunden wird relativ lang ist, sind die Ergebnisse dieser Studie schwer zu bewerten.

Zusammenfassend erscheint es dass die nicht-invasive Doppleruntersuchung der Arteria mammaria interna eine vielversprechende Technik ist. Ihr Stellenwert muss in weiteren Vergleichsstudien mit Standard Katheter Techniken untersucht werden. 


\section{CONCLUSIES EN SAMENVATTING}

De behandeling van coronarialijden bestaat vaak uit bypass chirurgie. Bij voorkeur wordt hierbij gebruik gemaakt van de arteria mammaria interna vanwege de uitstekende lange termijn resultaten, die hiermee worden bereikt. Na een beschrijving van de ontwikkeling van de coronairchirurgie, met name met betrekking tot de arteria mammaria interna in hoofdstuk 2, worden diverse aspecten van deze graft bediscussieerd. Systematisch onderzoek naar atherosclerotische veranderingen van de arteria mammaria interna is betrekkelijk weinig gedaan, terwijl in de meeste studies ook patiënten zonder coronarialijden werden ingesloten. Hoofdstuk 3 laat zien dat angiografisch aantoonbare atherosclerotische veranderingen bij patiënten met belangrijk coronarialijden relatief zeldzaam zijn. Routinematige preoperatieve angiografie van de arteria mammaria interna lijkt dan ook onnodig.

Een vergelijking van de preoperatieve angiografische bevindingen met betrekking tot de arteria mammaria interna met het daadwerkelijk intraoperatief gebruik van het vat heeft tot nu toe niet plaats gevonden. In hoofdstuk 4 worden de angiografische resultaten en de intraoperatieve bruikbaarheid, zoals die beoordeeld werd door de thoraxchirurg, vergeleken. Het blijkt dat meer arteriae mammariae internae worden afgewezen als graft dan alleen die met atherosclerotische veranderingen. Mogelijke redenen voor dit verschil zijn spasmen of intraoperatieve vaatbeschadiging.

Het gebruik van de arteria mammaria interna bij patiënten met een verhoogd operatierisico is een punt van discussie. De resultaten bij verschillende groepen zijn nog niet systematisch vergeleken. Wij hebben de resultaten onderzocht bij twee groepen patiënten met verhoogd operatierisico, namelijk hoofdstamstenose en instabiele angina pectoris. Hoofdstuk 5 beschrijft de gunsti- 
ge resultaten van een operatie met de arteria mammaria interna bij de groep patiënten met een hoofdstamstenose. Bij patiënten met instabiele angina pectoris daarentegen worden ongunstige resultaten gevonden (hoofdstuk 6). Blijkbaar profiteren niet alle patiënten met een verhoogd operatierisico van een operatie met de arteria mammaria interna. Verder onderzoek op dit gebied is nodig om de beste behandelingswijze voor elke patiënt vast te stellen. Dit zou kunnen leiden tot een meer gedifferentieerd gebruik van de arteria mammaria interna.

Kennis van de functie van de graft bij postoperatieve patiënten is van belang wanneer opnieuw symptomen van coronarialijden manifest worden. Tot op heden is angiografie de enige gebruikte methode, maar een arteria mammaria graft is vrij moeilijk selectief goed zichtbaar te maken met deze techniek. Bovendien zou een niet invasieve methode zoals Doppleronderzoek de voorkeur verdienen. In hoofdstuk 7 wordt aangetoond dat het zeer wel mogelijk is vanuit de fossa supraclavicularis een goed Dopplersignaal van de arteria mammaria interna te verkrijgen, zowel vóór als na bypasschirurgie waarbij dit vat als bypass gebruikt is. Met behulp van het Dopplersignaal lijkt men een goede indruk over de functie van de graft te krijgen.

Op zoek naar de optimale plaats voor het verkrijgen van een Dopplersignaal worden in hoofdstuk 8 de fossa supraclavicularis en de hoge intercostaalruimten met elkaar vergeleken. Het blijkt dat vanuit de intercostaalruimten minder vaak goede signalen verkregen worden.

Onderzoek na inspanning (hoofdstuk 9) toont veranderingen in het Dopplerflowpatroon vergeleken met de uitgangswaarden in rusttoestand. Daar echter de tijd tussen het einde van het inspanningsonderzoek en het verkrijgen van een goed Dopplersignaal vrij lang is, is het moeilijk hieruit conclusies te trekken.

Samenvattend lijkt Doppleronderzoek van de arteria mammaria interna graft een veelbelovende techniek. De waarde ervan vergeleken met de gebruikelijke cathetertechniek zal in verdere studies moeten blijken. 


\section{CURRICULUM VITAE}

RUUD KRINE

1954 geboren op 10 december te Beek en Donk, Nederland

1973 eindexamen gymnasium- $\beta$ aan het Carolus Borromeus College te Helmond

1980 artsexamen aan de Rijksuniversiteit te Utrecht

1981 begin opleiding interne geneeskunde Sint Joseph Ziekenhuis te Eindhoven (opleider Dr. P.F.L. Deckers)

1982 begin opleiding cardiologie Academisch Ziekenhuis Maastricht (opleider Prof. dr. H.J.J. Wellens)

1987 aanstelling als cardioloog aan de Evangelische Krankenanstalten Duisburg-Nord, Duitsland

1992 aanstelling als cardioloog aan het Maaslandziekenhuis te Sittard 



\section{TOT SLOT}

Gaarne wil ik mijn promotor professor dr. H.J.J. Wellens danken dat hij de begeleiding van dit proefschrift op zich wilde nemen en voor zijn hulp bij de bewerking ervan. Tijdens mijn opleiding tot cardioloog hebben zijn klinisch inzicht en zijn wetenschappelijk werk altijd grote indruk op mij gemaakt. Het is mij dan ook een genoegen juist bij hem te mogen promoveren.

Auch Ihnen, Herr Dr. Heinrich, möchte ich von ganzem Herzen danken für Ihre Unterstützung bei der Durchführung der hier beschriebenen Studien, die alle bei Ihnen im Herzzentrum durchgeführt werden konnten. Mein Dank gilt auch Herrn Dr. Ralf Lyttwin der an einigen dieser Studien sehr wesentlich beteiligt war sowie allen Kollegen im KWK für ihre Hilfebereitschaft. Auch den Damen des Sekreteriats danke ich für die Beschaffung der Akten und das Einbestellen der Patienten. 
